\title{
MERCURY CONTROL WITH THE ADVANCED HYBRID PARTICULATE COLLECTOR
}

Technical Progress Report

for the period July 1 through September 30, 2002

Prepared for:

AAD Document Control

U.S. Department of Energy

National Energy Technology Laboratory

PO Box 10940, MS 921-107

Pittsburgh, PA 15236-0940

DOE NETL Cooperative Agreement DE-FC26-01NT41184; UND Fund 4498

Performance Monitor: William Aljoe

Prepared by:

Stanley J. Miller

Ye Zhuang

Michelle R. Olderbak

Energy \& Environmental Research Center

University of North Dakota

PO Box 9018

Grand Forks, ND 58202-9018

November 2002 


\section{EERC DISCLAIMER}

LEGAL NOTICE This research report was prepared by the Energy \& Environmental Research Center (EERC), an agency of the University of North Dakota, as an account of work sponsored by National Energy Technology Laboratory. Because of the research nature of the work performed, neither the EERC nor any of its employees makes any warranty, express or implied, or assumes any legal liability or responsibility for the accuracy, completeness, or usefulness of any information, apparatus, product, or process disclosed, or represents that its use would not infringe privately owned rights. Reference herein to any specific commercial product, process, or service by trade name, trademark, manufacturer, or otherwise does not necessarily constitute or imply its endorsement or recommendation by the EERC.

\section{DISCLAIMER}

This report was prepared as an account of work sponsored by an agency of the United States Government. Neither the United States Government, nor any agency thereof, nor any of their employees makes any warranty, express or implied, or assumes any legal liability or responsibility for the accuracy, completeness, or usefulness of any information, apparatus, product, or process disclosed or represents that its use would not infringe privately owned rights. Reference herein to any specific commercial product, process, or service by trade name, trademark, manufacturer, or otherwise does not necessarily constitute or imply its endorsement, recommendation, or favoring by the United States Government or any agency thereof. The views and opinions of authors expressed herein do not necessarily state or reflect those of the United States Government or any agency thereof.

This report is available to the public from the National Technical Information Service, U.S. Department of Commerce, 5285 Port Royal Road, Springfield, VA 22161; phone orders accepted at (703) 487-4650.

\section{ACKNOWLEDGMENT}

This report was prepared with the support of the U.S. Department of Energy (DOE) National Energy Technology Laboratory Cooperative Agreement No. DE-FC26-01NT41184. However, any opinions, findings, conclusions, or recommendations expressed herein are those of the author(s) and do not necessarily reflect the views of DOE. 


\title{
MERCURY CONTROL WITH THE ADVANCED HYBRID PARTICULATE COLLECTOR
}

\begin{abstract}
This project was awarded under U.S. Department of Energy (DOE) National Energy Technology Laboratory (NETL) Program Solicitation DE-PS26-00NT40769 and specifically addresses Technical Topical Area 4 - Testing Novel and Less Mature Control Technologies on Actual Flue Gas at the Pilot Scale. The project team includes the Energy \& Environmental Research Center (EERC) as the main contractor; W.L. Gore \& Associates, Inc., as a technical and financial partner; and the Big Stone Power Plant operated by Otter Tail Power Company, host for the field-testing portion of the research.
\end{abstract}

Since 1995, DOE has supported development of a new concept in particulate control called the advanced hybrid particulate collector (AHPC). The AHPC has been licensed to W.L. Gore \& Associates, Inc., and is now marketed as the ADVANCED HYBRID ${ }^{\mathrm{TM}}$ Filter by Gore. The AHPC combines the best features of electrostatic precipitators (ESPs) and baghouses in a unique configuration, providing major synergism between the two collection methods, both in the particulate collection step and in the transfer of dust to the hopper. The AHPC provides ultrahigh collection efficiency, overcoming the problem of excessive fine-particle emissions with conventional ESPs, and it solves the problem of reentrainment and re-collection of dust in conventional baghouses. The AHPC appears to have unique advantages for mercury control over baghouses or ESPs as an excellent gas-solid contactor.

The objective of the three-task project is to demonstrate $90 \%$ total mercury control in the AHPC at a lower cost than current mercury control estimates. The approach includes bench-scale batch testing that ties the new work to previous results and links results with larger-scale pilot testing with real flue gas on a coal-fired combustion system, pilot-scale testing on a coal-fired combustion system with both a pulse-jet baghouse and an AHPC to prove or disprove the research hypotheses, and field demonstration pilot-scale testing at a utility power plant to prove scaleup and demonstrate longer-term mercury control.

This project, if successful, will demonstrate at the pilot-scale level a technology that would provide a cost-effective technique to accomplish control of mercury emissions and, at the same time, greatly enhance fine particulate collection efficiency. The technology can be used to retrofit systems currently employing inefficient ESP technology as well as for new construction, thereby providing a solution to a large segment of the U.S. utility industry as well as other industries requiring mercury control. 


\section{TABLE OF CONTENTS}

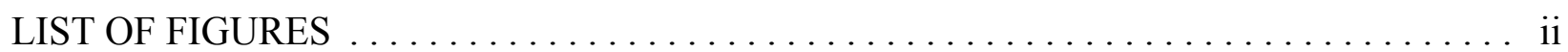

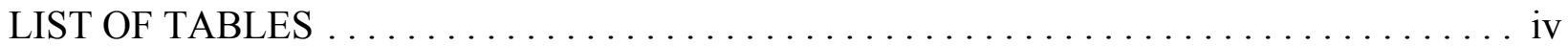

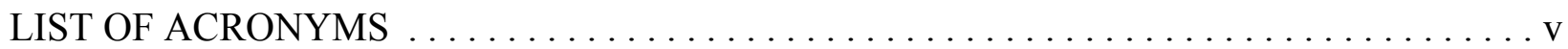

EXECUTIVE SUMMARY $\ldots \ldots \ldots \ldots \ldots \ldots \ldots \ldots \ldots \ldots \ldots \ldots$ vi

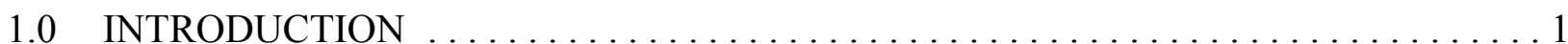

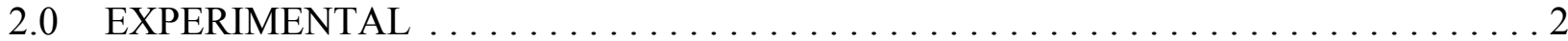

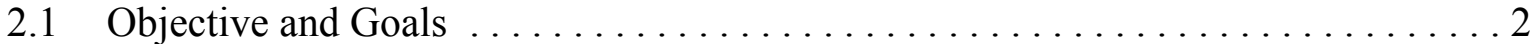

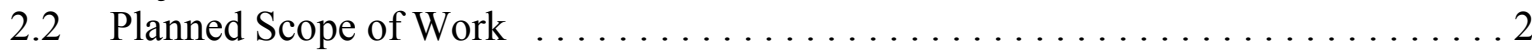

2.2.1 Task 1 - Project Management, Reporting, and Technology Transfer . . ... 2

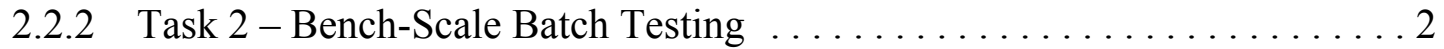

2.2.3 Task 3 - Pilot-Scale Testing . ........................... 5

2.2.4 Task 4 - Field Demonstration Pilot Testing .................. 6

2.2.5 Task 5 - Facility Removal and Disposition $\ldots \ldots \ldots \ldots \ldots \ldots \ldots$

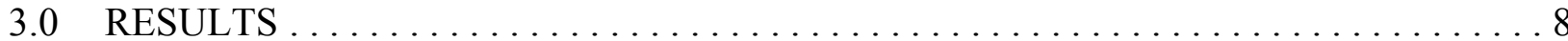

$3.1 \quad$ Big Stone Fuel Burn Record $\ldots \ldots \ldots \ldots \ldots \ldots \ldots \ldots \ldots \ldots \ldots \ldots \ldots \ldots \ldots \ldots$

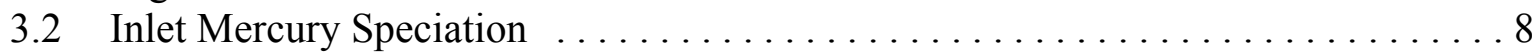

3.3 Baseline Mercury Capture Without Carbon Injection ................... 14

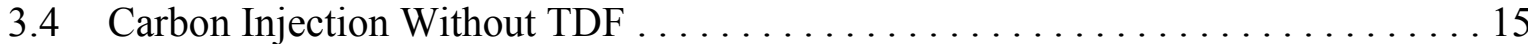

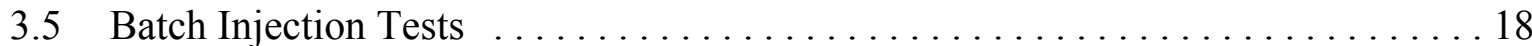

3.6 Effect of Supplemental TDF on Mercury Removal .................... 19

3.7 Effect of Current on Mercury Removal ............................... 19

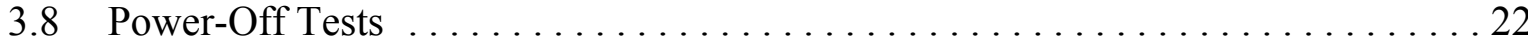

3.9 Stack Mercury and Particulate Measurements $\ldots \ldots \ldots \ldots \ldots \ldots \ldots \ldots \ldots . \ldots 22$

3.10 Effect of Carbon Injection on AHPC Performance $\ldots \ldots \ldots \ldots \ldots \ldots \ldots \ldots \ldots$

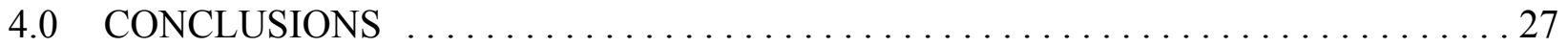

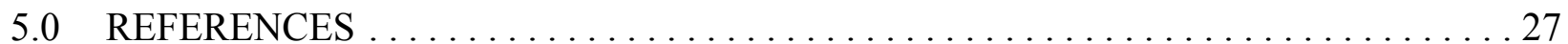




\section{LIST OF FIGURES}

1 Inlet mercury species distributions for the AHPC at Big Stone, August $5-9 \ldots \ldots \ldots 10$

2 Inlet mercury species distributions for the AHPC at Big Stone, August 26-27 $\ldots \ldots \ldots 10$

3 Summary of mercury species at the AHPC inlet from August to September $2002 \ldots \ldots 11$

4 Daily average of inlet mercury species in flue gas at Big Stone $\ldots \ldots \ldots \ldots \ldots \ldots 12$

5 Comparison of mercury species distribution for the AHPC at the Big Stone Plant and

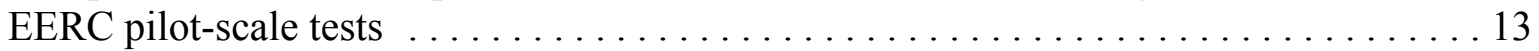

6 Inlet and outlet Ontario Hydro mercury speciation for the AHPC baseline test at

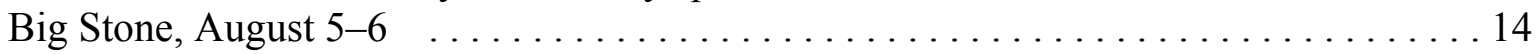

$7 \quad$ Mercury species concentration in flue gas at the AHPC inlet and outlet

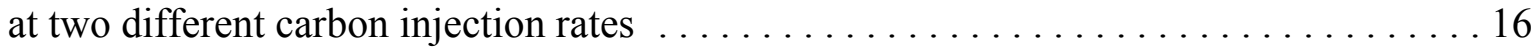

8 August 8 mercury species concentration in flue gas at the AHPC inlet and outlet at $0.29 \mathrm{~kg} / \mathrm{hr}$ carbon injection ................................. 17

9 Overall mercury collection efficiency at $0.29 \mathrm{~kg} / \mathrm{hr}$ carbon injection, August $7-9 \ldots \ldots 17$

10 Ontario Hydro and CMM measurements of collection efficiency by the AHPC at $0.29 \mathrm{~kg} / \mathrm{hr}$ carbon injection ................................... 18

11 Mercury species concentration in flue gas at the AHPC inlet and outlet for continuous and batch carbon injection, August $26-27 \ldots \ldots \ldots \ldots \ldots \ldots 20$

12 Mercury collection efficiency for continuous and batch carbon injection tests,

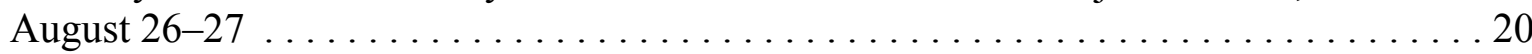

13 Total mercury vapor capture efficiency at Big Stone during the

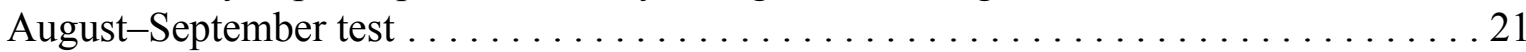

14 Inlet and outlet mercury CMM data, August $21-23 \ldots \ldots \ldots \ldots \ldots \ldots \ldots \ldots \ldots \ldots$

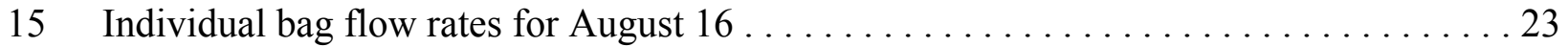

16 Mercury species in flue gas at the AHPC Big Stone stack $\ldots \ldots \ldots \ldots \ldots \ldots \ldots 23$

Continued... 


\section{LIST OF FIGURES (cont.)}

17 Average daily pressure drop for June $28-$ September $3 \ldots \ldots \ldots \ldots \ldots \ldots \ldots$

18 Daily average bag-cleaning interval for June 28 -September $3 \ldots \ldots \ldots \ldots \ldots$

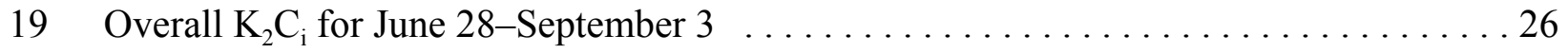

20 Overall minimum drag for June $28-$ September $3 \ldots \ldots \ldots \ldots \ldots \ldots \ldots \ldots \ldots$ 


\section{LIST OF TABLES}

1 Bench-Scale Series $1-\mathrm{SO}_{2}$ and $\mathrm{NO}_{2}$ Concentration $\ldots \ldots \ldots \ldots \ldots \ldots \ldots \ldots$

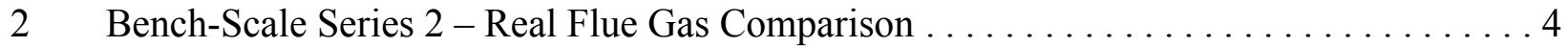

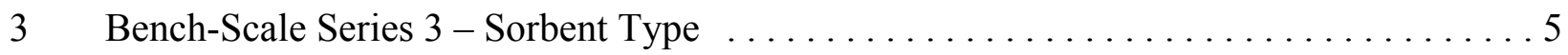

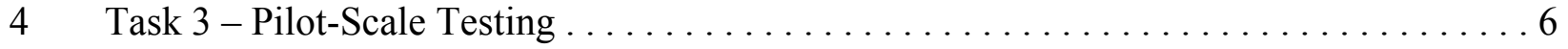

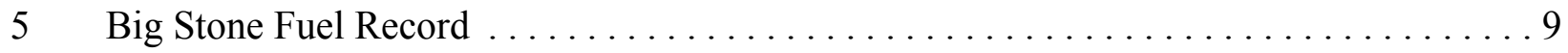

6 Chlorine Concentration in Flue Gas at Big Stone Plant $\ldots \ldots \ldots \ldots \ldots \ldots \ldots \ldots$

7 Standard Operating Conditions During August 5-September 6, $2002 \ldots \ldots \ldots$

8 Big Stone Plant Stack Emissions $\ldots \ldots \ldots \ldots \ldots \ldots \ldots \ldots \ldots \ldots \ldots \ldots \ldots \ldots \ldots \ldots$ 


\section{LIST OF ACRONYMS}

AHPC advanced hybrid particulate collector

A/C air-to-cloth

CMM continuous mercury monitor

DOE U.S. Department of Energy

EB eastern bituminous

EERC Energy \& Environmental Research Center

EPA U.S. Environmental Protection Agency

ESP electrostatic precipitator

IAC iodine-impregnated activated carbon

NETL National Energy Technology Laboratory

PJBH pulse-jet baghouse

PRB Powder River Basin

PTC particulate test combustor

TDF tire-derived fuel

WSB western subbituminous 


\section{MERCURY CONTROL WITH THE ADVANCED HYBRID PARTICULATE COLLECTOR}

\section{EXECUTIVE SUMMARY}

Since 1995, the U.S. Department of Energy (DOE) National Energy Technology Laboratory (NETL) has supported development of a new concept in particulate control called the advanced hybrid particulate collector (AHPC). The AHPC has been licensed to W.L. Gore \& Associates, Inc., and is now marketed as the ADVANCED HYBRID ${ }^{\mathrm{TM}}$ Filter by Gore. The AHPC combines the best features of electrostatic precipitators (ESPs) and baghouses in a unique configuration, providing major synergism between the two collection methods, both in the particulate collection step and in the transfer of dust to the hopper.

The objective of this project is to demonstrate $90 \%$ total mercury control with commercially available sorbents in the AHPC at a lower cost than current mercury control estimates. The approach includes three levels of testing: 1) bench-scale batch testing that ties the new work to previous results and links results with larger-scale pilot testing with real flue gas on a coal-fired combustion system, 2) pilot-scale testing on a previously proven combustion system with both a pulse-jet baghouse and an AHPC to prove or disprove the research hypotheses, and 3 ) field demonstration pilot-scale testing at a utility power plant to prove scaleup and demonstrate longer-term mercury control.

Initial bench-scale results were in good agreement with previous data. Results showed that the $\mathrm{SO}_{2}$ and $\mathrm{NO}_{2}$ concentration effects are additive and have a significant effect on sorbent performance. This finding should facilitate predicting sorbent performance in real systems when the $\mathrm{SO}_{2}$ and $\mathrm{NO}_{2}$ concentrations are known.

An initial field test of the 2.5-MW AHPC at Big Stone was completed the first week of November 2001. Results showed that the average inlet mercury speciation for seven samples was $55.4 \%$ particulate bound, $38.1 \%$ oxidized, and $6.4 \%$ elemental. A carbon injection rate of $24 \mathrm{~kg}$ of carbon sorbent/million $\mathrm{m}^{3}$ of flue gas ( $1.5 \mathrm{lb}$ of carbon sorbent/million acf) resulted in $91 \%$ total mercury collection efficiency, compared to $49 \%$ removal for the baseline case.

Following the initial field test, additional bench-scale tests, as well as the first planned pilot-scale tests, were completed. A key finding from the bench-scale tests was that the fixed-bed sorbent-screening tests using simulated flue gas were in good agreement with similar tests sampling real flue gas. This suggests that as long as the main flue gas components are duplicated, the bench-scale fixed-bed tests can be utilized to indicate sorbent performance in larger-scale systems.

In the pilot-scale tests, a baseline comparison was made between the AHPC and a pulse-jet baghouse in terms of the mercury speciation change across the device and the amount of mercury retained by the fly ash. Results showed that for both devices there was very little capture of mercury by the fly ash. There was some increase in oxidized mercury, but no significant differences were noted between the AHPC and pulse-jet modes of operation. 
Even though the same coal was used in the pilot-scale and initial field tests, there was a significant difference in inlet mercury speciation. For the pilot-scale tests, results were more similar to what is typically expected for Powder River Basin (PRB) coals in that most of the mercury was elemental, with little mercury capture by the fly ash. In contrast, for the November field test, there was much more oxidized than elemental mercury and significant mercury capture by the fly ash. Possible reasons for the difference include higher carbon in the field ash, somewhat higher $\mathrm{HCl}$ in the field flue gas, possible variation in the coal, cyclone firing for the field compared to pulverized coal firing for the pilot tests, longer residence time for the field tests, and a finer particle size for the field test.

During the last quarter (April-June 2002), a number of baseline and carbon injection tests were completed with Belle Ayr PRB subbituminous coal, one of the coals currently being burned at Big Stone. For the baseline case, approximately $70 \%$ of the inlet mercury was elemental, approximately $23 \%$ oxidized, and $2 \%$ or less was associated with particulate matter. There was very little natural mercury capture across the AHPC for the baseline tests and only a slight increase in the level of oxidized mercury across the AHPC during baseline operation.

With carbon injection, a comparison of short and long residence time in the AHPC showed that somewhat better mercury removal was achieved with longer residence time. No evidence of desorption of mercury from the carbon was seen upon continued exposure to flue gases up to 24 hours. This suggests that desorption of captured mercury from the carbon sorbent is not a significant problem under these flue gas conditions with the low-sulfur subbituminous coal.

At a carbon-to-mercury ratio of $3000: 1$, from $50 \%$ to $71 \%$ total mercury was achieved. When the ratio was increased to $6000: 1$, the removal increased the range to $65 \%-87 \%$. These results are highly encouraging because this level of control was achieved for the very difficult case with predominantly elemental mercury and very little natural capture of mercury by the fly ash.

A longer-term field test was completed with the 2.5-MW field AHPC August 6 through September 6, 2002. Carbon injection and mercury CMM (continuous mercury monitor) measurements were continuous ( 24 hours a day) for the entire month except for an unplanned plant outage from August 29 to September 2. The primary goal of the work was to demonstrate longer-term mercury control with the AHPC and evaluate the effect of the carbon injection on the AHPC operational performance. Another goal of the test was to evaluate the effect of supplemental tire burning on the level of mercury capture for comparison with results from the previous test completed in November 2001.

The inlet mercury speciation during the August 2002 tests averaged 17\% particulate bound, $32 \%$ oxidized, and $51 \%$ elemental. The significant difference in mercury speciation between the August field data and the November field data is likely the effect of a higher rate of cofiring of tire-derived fuel (TDF) with the coal during the November test.

In the November tests, $49 \%$ mercury capture was seen for the baseline conditions without carbon injection. The August tests indicated only from $0 \%$ to $10 \%$ mercury capture with no 
carbon injection. Again, the most likely explanation is the much higher TDF cofiring rate and higher $\mathrm{HCl}$ in the flue gas for the November test.

Addition of activated carbon at a rate of $24 \mathrm{~kg}$ of carbon sorbent $/ \mathrm{million} \mathrm{m}^{3}$ of flue gas (1.5 lb of carbon sorbent/million acf) resulted in an average of $63 \%$ mercury removal in the August tests without any TDF cofiring. A small TDF cofiring rate of about 23 tons per day resulted in an increase in mercury collection to $68 \%$. At the highest TDF rate seen in the August tests of 150-177 tons per day, mercury removal of up to $88 \%$ was achieved. This compares with $91 \%$ removal seen during the November tests when the TDF feed rate was in the range from 90 to 250 tons per day. These results indicate that TDF cofiring has the effect of increasing the level of mercury control that can be achieved with a low carbon addition rate.

One of the main objectives of the August tests was to assess the effect of carbon injection on longer-term AHPC performance. When the carbon was started on August 7, there was no perceptible change in pressure drop or bag-cleaning interval. Similarly, there was no change in the $\mathrm{K}_{2} \mathrm{C}_{\mathrm{i}}$ value that relates to how well the ESP portion of the AHPC is working. These results indicate that low addition rates of carbon will have no perceptible effect on the operational performance of the AHPC. 


\section{MERCURY CONTROL WITH THE ADVANCED HYBRID PARTICULATE COLLECTOR}

\subsection{INTRODUCTION}

This project was awarded under U.S. Department of Energy (DOE) National Energy Technology Laboratory (NETL) Program Solicitation DE-PS26-00NT40769 and specifically addresses Technical Topic Area 4 - Testing Novel and Less Mature Control Technologies on Actual Flue Gas at the Pilot Scale. The project team includes the Energy \& Environmental Research Center (EERC) as the main contractor; W.L. Gore \& Associates, Inc., as a technical and financial partner; and the Big Stone Power Plant operated by Otter Tail Power Company, which is hosting the field testing portion of the research.

Since 1995, DOE has supported development of a new concept in particulate control called the advanced hybrid particulate collector (AHPC). The AHPC has been licensed to W.L. Gore \& Associates, Inc., and is now marketed as the ADVANCED HYBRID ${ }^{\text {TM }}$ Filter by Gore. The AHPC combines the best features of electrostatic precipitators (ESPs) and baghouses in a unique configuration, providing major synergism between the two collection methods, both in the particulate collection step and in the transfer of dust to the hopper. The AHPC provides ultrahigh collection efficiency, overcoming the problem of excessive fine-particle emissions with conventional ESPs, and it solves the problem of reentrainment and re-collection of dust in conventional baghouses. In Phase II of the DOE-funded AHPC project, a 2.5-MW-scale AHPC was designed, constructed, installed, and tested at the Big Stone Power Plant. For Phase III, further testing of an improved version of the 2.5-MW-scale AHPC at the Big Stone Power Plant was conducted to facilitate commercialization of the AHPC technology. The AHPC appears to have unique advantages for mercury control over baghouses or ESPs as an excellent gas-solid contactor.

The objective of this project is to demonstrate $90 \%$ total mercury control with commercially available sorbents in the AHPC at a lower cost than current mercury control estimates. The approach includes three levels of testing: 1) bench-scale batch testing that ties the new work to previous results and links results with larger-scale pilot testing with real flue gas on a coal-fired combustion system, 2) pilot-scale testing on a previously proven combustion system with both a pulse-jet baghouse and an AHPC to prove or disprove the research hypotheses, and 3) field demonstration pilot-scale testing at a utility power plant to prove scaleup and demonstrate longer-term mercury control. 


\subsection{EXPERIMENTAL}

\subsection{Objective and Goals}

The overall project objective is to demonstrate $90 \%$ total mercury control with commercially available sorbents in the AHPC at a lower cost than current mercury control estimates.

Test goals include the following:

- Determine if the bench-scale mercury breakthrough results can be duplicated when real flue gas is sampled.

- Compare the level of mercury control with sorbents under similar conditions at the $55-\mathrm{kW}$ pilot scale between the AHPC and a pulse-jet baghouse.

- Demonstrate $90 \%$ mercury capture for both a western subbituminous and an eastern bituminous coal.

- Demonstrate mercury capture with the 2.5-MW AHPC at Big Stone.

- Demonstrate $90 \%$ mercury capture over a longer time (3 months) with the $2.5-\mathrm{MW}$ AHPC at Big Stone.

\subsection{Planned Scope of Work}

To meet the objectives, the work was organized into five tasks:

- Task 1: Project Management, Reporting, and Technology Transfer

- Task 2: Bench-Scale Batch Testing

- Task 3: Pilot-Scale Testing

- Task 4: Field Demonstration Pilot Testing

- Task 5: Facility Removal and Disposition

\subsubsection{Task 1 - Project Management, Reporting, and Technology Transfer}

Task 1 includes all of the project management requirements, including planning, coordination among team members, supervision of tests, review of results, meeting attendance, and all aspects of reporting.

\subsubsection{Task 2-Bench-Scale Batch Testing}

The bench-scale tests are for the purposes of verifying previous results, expanding on the $\mathrm{SO}_{2}$ and $\mathrm{NO}_{2}$ concentration effect, linking the synthetic gas results to the results with real flue gas, and screening sorbents. 
The 30 tests planned with the bench-scale unit are divided into three series that follow a logical progression. The purpose of the first series of tests is to ensure that results obtained by the EERC and others can be duplicated and, second, to include $\mathrm{SO}_{2}$ and $\mathrm{NO}_{2}$ as variables. Series 1 tests, shown in Table 1, are intended to verify the previous bench-scale work and expand on the $\mathrm{SO}_{2}$ and $\mathrm{NO}_{2}$ concentration effect. In previous work, no tests were completed in which both the $\mathrm{SO}_{2}$ and $\mathrm{NO}_{2}$ were reduced at the same time. In all of these tests, the inlet $\mathrm{Hg}^{0}$ concentration is typically $15 \mu \mathrm{g} / \mathrm{m}^{3}$, and each test is run for approximately $4 \mathrm{hr}$. The $150 \mathrm{mg}$ of NORIT Americas FGD activated carbon sorbent is equivalent to a sorbent-to-mercury ratio of 3700 after $3 \mathrm{hr}$ of exposure. This concentration has been shown to provide consistent results in previous testing and is sufficient to accurately measure the amount of mercury in the spent sorbent for mass balance closure. The Series 1 tests were previously completed, and results were reported in the January-March 2002 quarterly report.

The second series of bench-scale tests (Table 2) is for the purpose of comparing the benchscale fixed-bed results sampling real flue gas to those obtained with simulated flue gas for both a western subbituminous and an eastern bituminous coal. The simulated flue gas concentrations are based on the actual concentrations measured in the combustion tests. In addition, tests with lower sorbent concentrations will also be conducted with flue gases matched to the two coals to assist in selecting the best sorbent concentrations for the pilot-scale tests. The real flue gas tests are part of the first two pilot-scale tests in Task 3, using a slipstream bench-scale system sampling flue gas from the particulate test combustor (PTC).

Tests 11-14 of the Series 2 tests were previously completed, and results were presented in the January-March 2002 quarterly report. Tests 15-20 have not been completed yet because they are dependent on completion of pilot-scale tests with an eastern bituminous coal.

The third series of bench-scale tests (Table 3) is for the purpose of screening alternative sorbents. The iodine-impregnated activated carbon (IAC) sorbent was chosen because of the excellent results seen in some of the previous EERC pilot-scale tests, especially at higher temperatures from $121^{\circ}-177^{\circ} \mathrm{C}\left(250^{\circ}-350^{\circ} \mathrm{F}\right)$. IAC also appears to be better at capturing $\mathrm{Hg}^{0}$ than FGD. However, since IAC is more costly than FGD, it must be effective at lower concentrations than FGD. IAC will be evaluated with flue gas concentrations for both a subbituminous and a bituminous coal at two concentration levels and two temperatures. Four additional screening tests will be conducted on other promising alternative sorbents to be selected based on new information and availability. The results from these tests will be used to prescreen alternative sorbents that have the potential to provide better mercury capture than FGD. The most promising sorbent would then be further evaluated in pilot-scale testing in Task 3. None of the tests in Table 3 has been completed yet. However, a new promising noncarbon-based sorbent is being developed outside the EERC and is expected to be available for testing next quarter. 
Table 1. Bench-Scale Series $1-\mathrm{SO}_{2}$ and $\mathrm{NO}_{2}$ Concentration

\begin{tabular}{lcccccccc}
\hline $\begin{array}{l}\text { Test } \\
\text { No. }\end{array}$ & $\begin{array}{c}\text { Sorbent } \\
\text { Type }\end{array}$ & $\begin{array}{c}\text { Temp., } \\
{ }^{\circ} \mathrm{C}\end{array}$ & $\begin{array}{c}\text { Sorbent } \\
\text { Concentration, } \mathrm{mg}\end{array}$ & $\begin{array}{c}\text { Flue } \\
\text { Gas }\end{array}$ & $\begin{array}{c}\mathrm{SO}_{2}, \\
\mathrm{ppm}\end{array}$ & $\begin{array}{c}\mathrm{HCl}, \\
\mathrm{ppm}\end{array}$ & $\begin{array}{c}\mathrm{NO}, \\
\mathrm{ppm}\end{array}$ & $\begin{array}{c}\mathrm{NO}_{2}, \\
\mathrm{ppm}\end{array}$ \\
\hline 1 & FGD & 135 & 150 & Simulated & 1600 & 50 & 400 & 20 \\
2 & FGD & 135 & 150 & Simulated & 500 & 50 & 400 & 20 \\
3 & FGD & 135 & 150 & Simulated & 200 & 50 & 400 & 20 \\
4 & FGD & 135 & 150 & Simulated & 1600 & 50 & 400 & 10 \\
5 & FGD & 135 & 150 & Simulated & 500 & 50 & 400 & 10 \\
6 & FGD & 135 & 150 & Simulated & 200 & 50 & 400 & 10 \\
7 & FGD & 135 & 150 & Simulated & 1600 & 50 & 400 & 5 \\
8 & FGD & 135 & 150 & Simulated & 500 & 50 & 400 & 5 \\
9 & FGD & 135 & 150 & Simulated & 200 & 50 & 400 & 5 \\
10 & FGD & 135 & 150 & Simulated & Repeat test to be selected \\
\hline
\end{tabular}

Table 2. Bench-Scale Series 2 - Real Flue Gas Comparison

\begin{tabular}{|c|c|c|c|c|c|c|c|c|}
\hline $\begin{array}{l}\text { Test } \\
\text { No. }\end{array}$ & $\begin{array}{c}\text { Sorbent } \\
\text { Type }\end{array}$ & $\begin{array}{c}\text { Temp., } \\
{ }^{\circ} \mathrm{C}\end{array}$ & $\begin{array}{c}\text { Sorbent } \\
\text { Concentration, mg }\end{array}$ & $\begin{array}{l}\text { Flue } \\
\text { Gas }\end{array}$ & $\begin{array}{l}\mathrm{SO}_{2}, \\
\text { ppm }\end{array}$ & $\begin{array}{l}\mathrm{HCl}, \\
\mathrm{ppm}\end{array}$ & $\begin{array}{l}\mathrm{NO}, \\
\mathrm{ppm}\end{array}$ & $\begin{array}{l}\mathrm{NO}_{2}, \\
\text { ppm }\end{array}$ \\
\hline 11 & FGD & 135 & 150 & Real & \multicolumn{4}{|c|}{ Flue gas from western coal } \\
\hline 12 & FGD & 135 & 150 & Real & \multicolumn{4}{|c|}{ Duplicate test of western coal } \\
\hline 13 & FGD & 135 & 150 & Simulated* & 400 & 4 & 300 & 5 \\
\hline 14 & FGD & 135 & 150 & $\begin{array}{l}\text { Simulated } \\
\text { Duplicate* }\end{array}$ & 400 & 4 & 300 & 5 \\
\hline 15 & FGD & 135 & 50 & Simulated* & 400 & 4 & 300 & 5 \\
\hline 16 & FGD & 135 & 150 & Real & \multicolumn{4}{|c|}{ Flue gas from eastern coal } \\
\hline 17 & FGD & 135 & 150 & Real & \multicolumn{4}{|c|}{ Duplicate test of eastern coal } \\
\hline 18 & FGD & 135 & 150 & Simulated* & 1000 & 50 & 400 & 10 \\
\hline 19 & FGD & 135 & 150 & $\begin{array}{l}\text { Simulated } \\
\text { Duplicate* }\end{array}$ & 1000 & 50 & 400 & 10 \\
\hline 20 & FGD & 135 & 50 & Simulated* & 1000 & 50 & 400 & 10 \\
\hline
\end{tabular}

* Simulated flue gases will be determined from actual flue gas measurements during combustion tests; values shown are estimates. 
Table 3. Bench-Scale Series 3 - Sorbent Type

\begin{tabular}{|c|c|c|c|c|c|c|c|c|}
\hline $\begin{array}{l}\text { Test } \\
\text { No. }\end{array}$ & $\begin{array}{l}\text { Sorbent } \\
\text { Type }\end{array}$ & $\begin{array}{c}\text { Temp., } \\
{ }^{\circ} \mathrm{C}\end{array}$ & $\begin{array}{c}\text { Sorbent } \\
\text { Concentration, } \mathrm{mg}\end{array}$ & $\begin{array}{l}\text { Flue } \\
\text { Gas }\end{array}$ & $\begin{array}{l}\mathrm{SO}_{2}, \\
\mathrm{ppm}\end{array}$ & $\begin{array}{l}\mathrm{HCl}, \\
\mathrm{ppm}\end{array}$ & $\begin{array}{l}\text { NO, } \\
\text { ppm }\end{array}$ & $\begin{array}{l}\mathrm{NO}_{2}, \\
\text { ppm }\end{array}$ \\
\hline 21 & IAC & 135 & 150 & Simulated* & 400 & 4 & 300 & 5 \\
\hline 22 & IAC & 135 & 50 & Simulated* & 400 & 4 & 300 & 5 \\
\hline 23 & IAC & 135 & 150 & Simulated* & 1000 & 50 & 400 & 10 \\
\hline 24 & IAC & 135 & 50 & Simulated* & 1000 & 50 & 400 & 10 \\
\hline 25 & IAC & 163 & 150 & Simulated* & 400 & 4 & 300 & 5 \\
\hline 26 & IAC & 163 & 150 & Simulated* & 1000 & 50 & 400 & 10 \\
\hline 27 & New No. $1 * *$ & 135 & 150 & Simulated* & 400 & 4 & 300 & 5 \\
\hline 28 & New No. $2 * *$ & 135 & 150 & Simulated* & 400 & 4 & 300 & 5 \\
\hline 29 & New No. $3 * *$ & 135 & 150 & Simulated* & 400 & 4 & 300 & 5 \\
\hline 30 & New No. $4 * *$ & 135 & 150 & Simulated* & 400 & 4 & 300 & 5 \\
\hline
\end{tabular}

* Simulated flue gases will be determined from actual flue gas measurements during combustion tests; values shown are estimates.

** New sorbents will be selected based on background data and availability.

\subsubsection{Task 3-Pilot-Scale Testing}

Six weeks of testing are planned under Task 3. A week of testing includes an 8-hr heatup period on gas and then approximately $100 \mathrm{hr}$ of steady-state operation firing coal. This allows for four 24-hr test periods where the PTC is operated around the clock. The planned 6 weeks of tests are shown in Table 4. The first 2 weeks are for the purpose of generating baseline data without carbon injection for a bituminous and a subbituminous coal with both the pulse-jet baghouse and the AHPC. Each test is for a duration of approximately $48 \mathrm{hr}$. These tests will establish the amount of mercury capture by fly ash and will determine whether the amount of mercury capture is different between the pulse-jet baghouse and the AHPC. It will also establish the inlet and outlet speciated mercury concentrations and whether there is a change in mercury speciation across both devices. A second purpose for these baseline tests is to provide flue gas to support the bench-scale testing with real flue gas under Task 2.

Weeks 3 and 4 are designed to prove the ability of the technology to control mercury at the $90 \%$ level with a western subbituminous coal. Week 5 is for testing mercury control in the AHPC with an eastern bituminous coal.

Week 6 is for the purpose of testing alternative sorbents in the AHPC. The need for alternate sorbent testing will be somewhat dependent on the results with the FGD sorbent. If $90 \%$ mercury capture was already demonstrated with both coals at a low sorbent concentration (for example, less than 3000:1), then there may be no need to further evaluate other sorbents. In this case, Week 6 would be cancelled, and testing with the field AHPC would proceed. However, if results with the FGD sorbent have not met expectations and other sorbents look more 
Table 4. Task 3 - Pilot-Scale Testing

\begin{tabular}{|c|c|c|c|c|c|c|}
\hline $\begin{array}{l}\text { Week/ } \\
\text { Test }\end{array}$ & Purpose & Coal & $\begin{array}{c}\text { Collection } \\
\text { Device }\end{array}$ & $\begin{array}{c}\text { Sorbent } \\
\text { Type }\end{array}$ & $\begin{array}{l}\mathrm{C}: \mathrm{Hg} \\
\text { Ratio }\end{array}$ & $\begin{array}{c}\text { Injection } \\
\text { Method }\end{array}$ \\
\hline $1-1$ & Baseline & $\mathrm{WSB}^{1}$ & $\mathrm{PJBH}^{2}$ & None & $\mathrm{NA}^{3}$ & NA \\
\hline $1-2$ & Baseline & WSB & AHPC & None & NA & NA \\
\hline $2-1$ & Baseline & $\mathrm{EB}^{4}$ & PJBH & None & NA & NA \\
\hline $2-2$ & Baseline & EB & AHPC & None & NA & NA \\
\hline $3-1$ & Hg capture, collection device & WSB & $\mathrm{PJBH}$ & FGD & $3000^{5}$ & Continuous \\
\hline $3-2$ & Hg capture, collection device & WSB & AHPC & FGD & $3000^{5}$ & Continuous \\
\hline $4-1$ & $\mathrm{Hg}$ capture, residence time & WSB & AHPC & FGD & $3000^{5}$ & Continuous \\
\hline $4-2$ & $\mathrm{Hg}$ capture, residence time & WSB & AHPC & FGD & $3000^{5}$ & Batch \\
\hline $5-1$ & $\mathrm{Hg}$ capture, residence time & $\mathrm{EB}$ & AHPC & FGD & $3000^{5}$ & Continuous \\
\hline $5-2$ & $\mathrm{Hg}$ capture, residence time & $\mathrm{EB}$ & AHPC & FGD & $3000^{5}$ & Batch \\
\hline $6-1$ & Sorbent type and concentration & WSB & AHPC & New No. $1^{6}$ & $3000^{5}$ & Continuous $^{6}$ \\
\hline $6-2$ & Sorbent type and concentration & WSB & AHPC & New No. $1^{6}$ & $1000^{5}$ & Continuous $^{6}$ \\
\hline $6-3$ & Sorbent type and concentration & WSB & AHPC & New No. $2^{6}$ & $3000^{5}$ & Continuous $^{6}$ \\
\hline $6-4$ & Sorbent type and concentration & WSB & AHPC & New No. $2^{6}$ & $1000^{5}$ & Continuous $^{6}$ \\
\hline $\begin{array}{ll}{ }_{1}^{1} \text { Wes } \\
{ }^{2} \text { Puls } \\
{ }^{3} \text { Not } \\
{ }^{4} \text { East } \\
{ }^{5} \text { Estir }\end{array}$ & $\begin{array}{l}\text { ubbituminous. } \\
\text { aghouse. } \\
\text { able. } \\
\text { tuminous. } \\
\text { concentrations; actual concentrat } \\
\text { cted. }\end{array}$ & 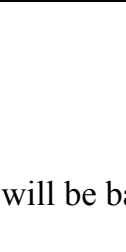 & 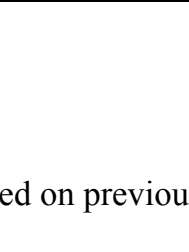 & 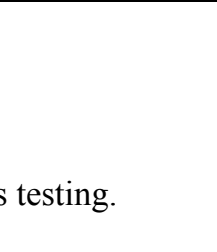 & & \\
\hline
\end{tabular}

promising or if other unanswered questions remain that could be tested in the pilot tests, Week 6 would be completed.

From the pilot-scale test matrix listed in Table 4, the first 3 weeks of testing with a western subbituminous coal have all been completed (Tests 1-1, 1-2, 3-1, 3-2, 4-1, and 4-2). Results from the first week of testing were reported in the January-March 2002 quarterly report. Results from Weeks 2-4 were presented later in the April-June 2002 quarterly report. Weeks 5 and 6 have not been completed yet.

\subsubsection{Task 4 - Field Demonstration Pilot Testing}

Demonstration of mercury control with the AHPC at the 2.5-MW scale at a utility power plant is the next logical step toward proving the commercial validity of this approach. A total of 5 months of field tests were originally planned. The first month was planned for baseline testing without sorbent injection to establish the mercury concentration, speciation, and amount of fly ash capture as well as to compare mercury emissions at the plant stack with the AHPC outlet. 
The second month of field tests was planned for the purpose of establishing the sorbent addition rate to achieve $90 \%$ mercury control. Depending on the level of success with the FGD sorbent in the field and the pilot-scale test results with alternative sorbents, the third month was planned for the purpose of evaluating alternative sorbents. If alternative sorbent testing is not done, then 3 months of longer-term testing with the FGD sorbent are to be completed. The longer-term operation will establish whether there are any longer-term problems associated with the sorbent injection such as bag-cleaning problems. If alternative sorbents are tested during Month 3, then the longer-term demonstration testing would last only 2 months.

According to the planned work, testing with the 2.5-MW AHPC at the Big Stone Power Plant was not scheduled to begin until after completion of the first pilot-scale tests. However, the project team decided to conduct an initial field test the first week of November 2001 prior to the pilot-scale tests at the EERC.

The field test at Big Stone was completed the week of November 5-10, 2001, with baseline testing on the first day, followed by carbon injection in both AHPC and pulse-jet operational modes for the remainder of the week. The starting carbon addition rate was set at $24 \mathrm{~kg}$ of carbon sorbent/million $\mathrm{m}^{3}$ of flue gas ( $1.5 \mathrm{lb}$ of carbon sorbent/million acf), with the plan that it could be increased if necessary to achieve good mercury control. However, over $90 \%$ mercury control was seen at this carbon addition rate, so no testing was completed at higher carbon concentrations. The results from the November field test were previously reported in the October-December 2001 quarterly report.

An additional month of mercury control testing was completed with the 2.5-MW field AHPC August 6 - September 6, 2002. Carbon injection along with continuous mercury monitor (CMM) measurements was completed during the entire month except during an unplanned plant outage during the period from August 29 to September 2. Results from this field test are presented in this quarterly report.

\subsubsection{Task 5 - Facility Removal and Disposition}

The field AHPC will be dismantled and removed at the end of this project if no further testing is anticipated in support of subsequent work at the Big Stone Power Plant. If further testing were to be completed with the field AHPC at another site (funded by possible subsequent projects), the AHPC components would be moved to that site. If no other AHPC testing is anticipated, the salvageable AHPC components will be returned to the EERC, and the larger steel components will be disposed of as scrap steel. The site will then be restored to its original condition. The Big Stone Power Plant will be responsible for removing the 24-in. ductwork that breeches the plant ductwork, electrical power lines, air supply lines, and communication lines once the project is complete. 


\subsection{RESULTS}

A longer-term field test was completed with the 2.5-MW field AHPC August 6 through September 6, 2002. Carbon injection and CMM measurements were continuous (24 hours a day) for the entire month except during an unplanned plant outage from August 29 to September 2. The primary goal of the work was to demonstrate longer-term mercury control with the AHPC and evaluate the effect of the carbon injection on the AHPC operational performance. Another goal of the test was to evaluate the effect of supplemental tire burning on the level of mercury capture for comparison with results from the previous test completed in November 2001. During the November test, the Big Stone Plant was burning approximately $3 \%-5 \%$ waste tires. During the start of the August test, the tire feed was deliberately stopped to evaluate mercury control without tire feed. The plan was then to start the tire feed again during the monthlong test. However, because of an unsteady supply of the waste tires, the tire feed rate was lower and more intermittent than the amount burned last November.

During the week of testing from August 5 to 9 and on August 26 and 27, Ontario Hydro mercury sampling was completed at both the AHPC inlet and outlet. Several Method 26A samples for $\mathrm{HCl}$ were also taken during the days when Ontario Hydro sampling was completed. Inlet and outlet mercury data were also taken with a single mercury monitor. For the majority of the time, the mercury monitor sampled at the outlet, but several times a day it was switched to the inlet for a short time to document the inlet concentration. On the days when Ontario Hydro sampling was not completed, the CMM was operated continuously for 24 hours a day. The CMM was normally set up to measure the outlet total vapor-phase mercury, but during the day for several hours, it was manually switched to measure both the total and elemental vapor-phase mercury at the inlet as well as the elemental mercury at the outlet.

\subsection{Big Stone Fuel Burn Record}

The fuel burn record from the plant data for the field test last November and the August 5-September 6, 2002, test is shown in Table 5. Last November, the coal was from either the Cordero or Caballo Mines in the Powder River Basin (PRB). For the August 5-September 6 test, the coal was from the Belle Ayr and Eagle Butte Mines. Both coals are similar low-sulfur subbituminous fuels from the PRB. The amounts of tire-derived fuel (TDF) and waste seed fuel burned during this time are also listed in Table 5. Waste tires are known to be a source of chlorine and thought to be the reason for the higher $\mathrm{HCl}$ seen in the flue gas last November (2, 3). Waste corn seed may also be a source of some additional chlorine, but the amount of inorganic material in the corn is expected to be less than in TDF.

\subsection{Inlet Mercury Speciation}

The Ontario Hydro inlet mercury speciation data from August 5-9 are shown in Figure 1, and August 26-27 data are shown in Figure 2. While there is some variability in the coal as well as analytical uncertainty, the data indicate fairly consistent mercury speciation. In Figure 3, the CMM data are shown alongside the Ontario Hydro data. No particulate mercury for the CMM is shown because the gas is sampled through a filter with a probe pointed downstream 
Table 5. Big Stone Fuel Record

\begin{tabular}{lcccc}
\hline Date & Coal Mine & Coal, tons & TDF, tons & Waste Seeds, tons \\
\hline November 5, 2001 & Cordero & 4695 & 140 & 100 \\
November 6, 2001 & Cordero & 6117 & 200 & 100 \\
November 7, 2001 & Caballo & 6104 & 150 & 120 \\
November 8, 2001 & Caballo & 6296 & 90 & 100 \\
November 9, 2001 & Caballo & 6024 & 250 & 80 \\
August 5, 2002 & Belle Ayr & 5947 & 0 & 18 \\
August 6, 2002 & Belle Ayr & 5945 & 0 & 0 \\
August 7, 2002 & Belle Ayr & 6096 & 0 & 46 \\
August 8, 2002 & Belle Ayr & 6312 & 0 & 0 \\
August 9, 2002 & Belle Ayr & 6135 & 16 & 157 \\
August 10, 2002 & Belle Ayr & 6473 & 0 & 0 \\
August 11, 2002 & Belle Ayr & 6242 & 0 & 0 \\
August 12, 2002 & Belle Ayr & 6418 & 23 & 92 \\
August 13, 2002 & Belle Ayr & 5531 & 23 & 88 \\
August 14, 2002 & Belle Ayr & 5525 & 22 & 64 \\
August 15, 2002 & Eagle Butte & 5793 & 25 & 50 \\
August 16, 2002 & Eagle Butte & 5867 & 0 & 69 \\
August 17, 2002 & Eagle Butte & 5344 & 0 & 0 \\
August 18, 2002 & Eagle Butte & 5278 & 0 & 0 \\
August 19, 2002 & Eagle Butte & 5121 & 20 & 24 \\
August 20, 2002 & Eagle Butte & 5895 & 51 & 33 \\
August 21, 2002 & Eagle Butte & 5951 & 177 & 0 \\
August 22, 2002 & Eagle Butte & 5771 & 150 & 0 \\
August 23, 2002 & Eagle Butte & 5827 & 0 & 169 \\
August 24, 2002 & Belle Ayr & 6100 & 0 & 0 \\
August 25, 2002 & Belle Ayr & 5878 & 0 & 0 \\
August 26, 2002 & Belle Ayr & 6040 & 0 & 0 \\
August 27, 2002 & Belle Ayr & 5862 & 24 & 0 \\
August 28, 2002 & Belle Ayr & 2488 & 0 & 0 \\
September 3, 2002 & Eagle Butte & 5996 & 23 & 0 \\
September 4, 2002 & Belle Ayr & 6298 & 0 & 0 \\
September 5, 2002 & Belle Ayr & 6336 & 0 & 0 \\
September 6,2002 & Eagle Butte & 6186 & 45 & 0 \\
\hline & & & & 0 \\
\hline
\end{tabular}




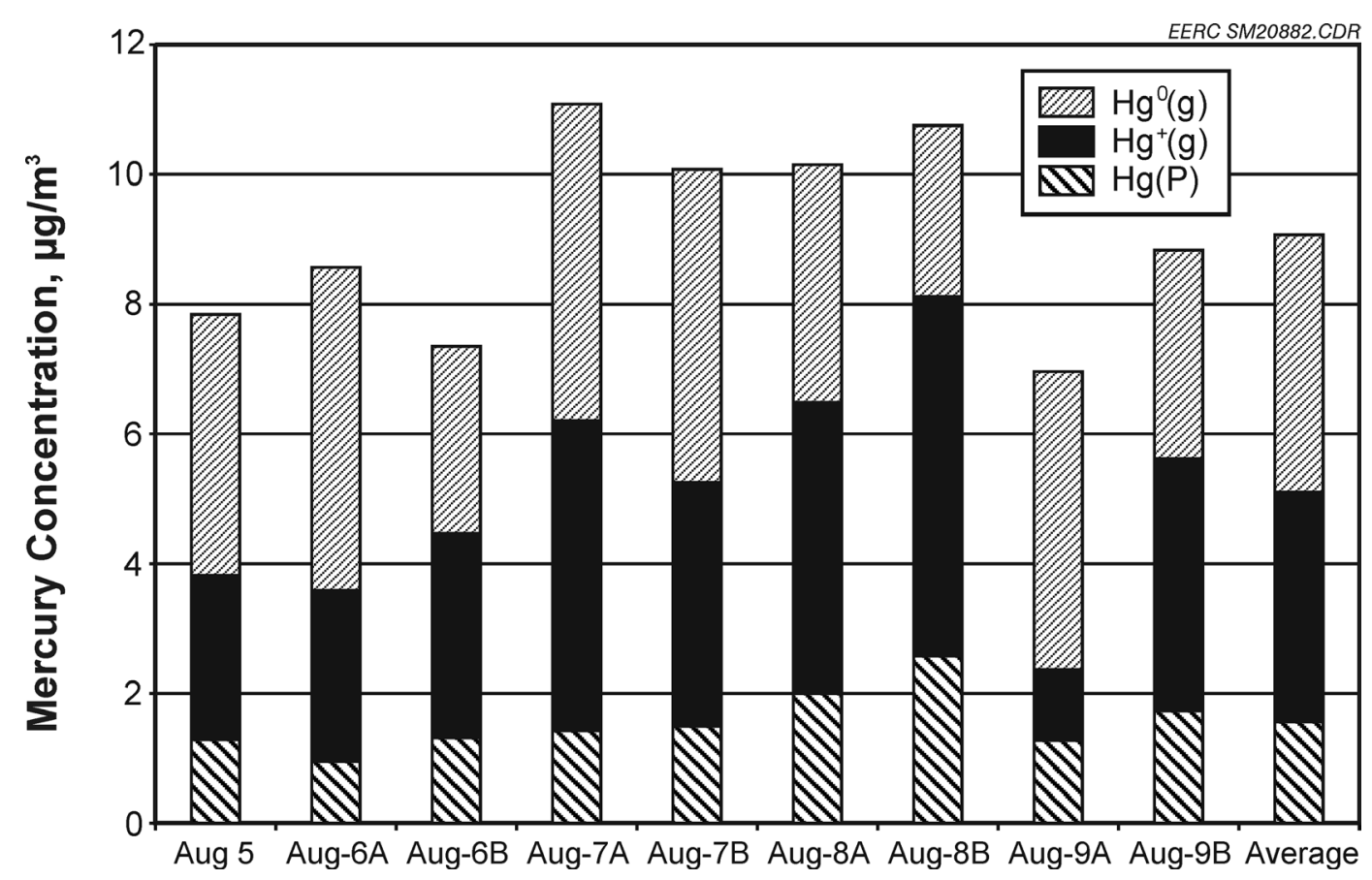

Figure 1. Inlet mercury species distributions for the AHPC at Big Stone, August 5-9.

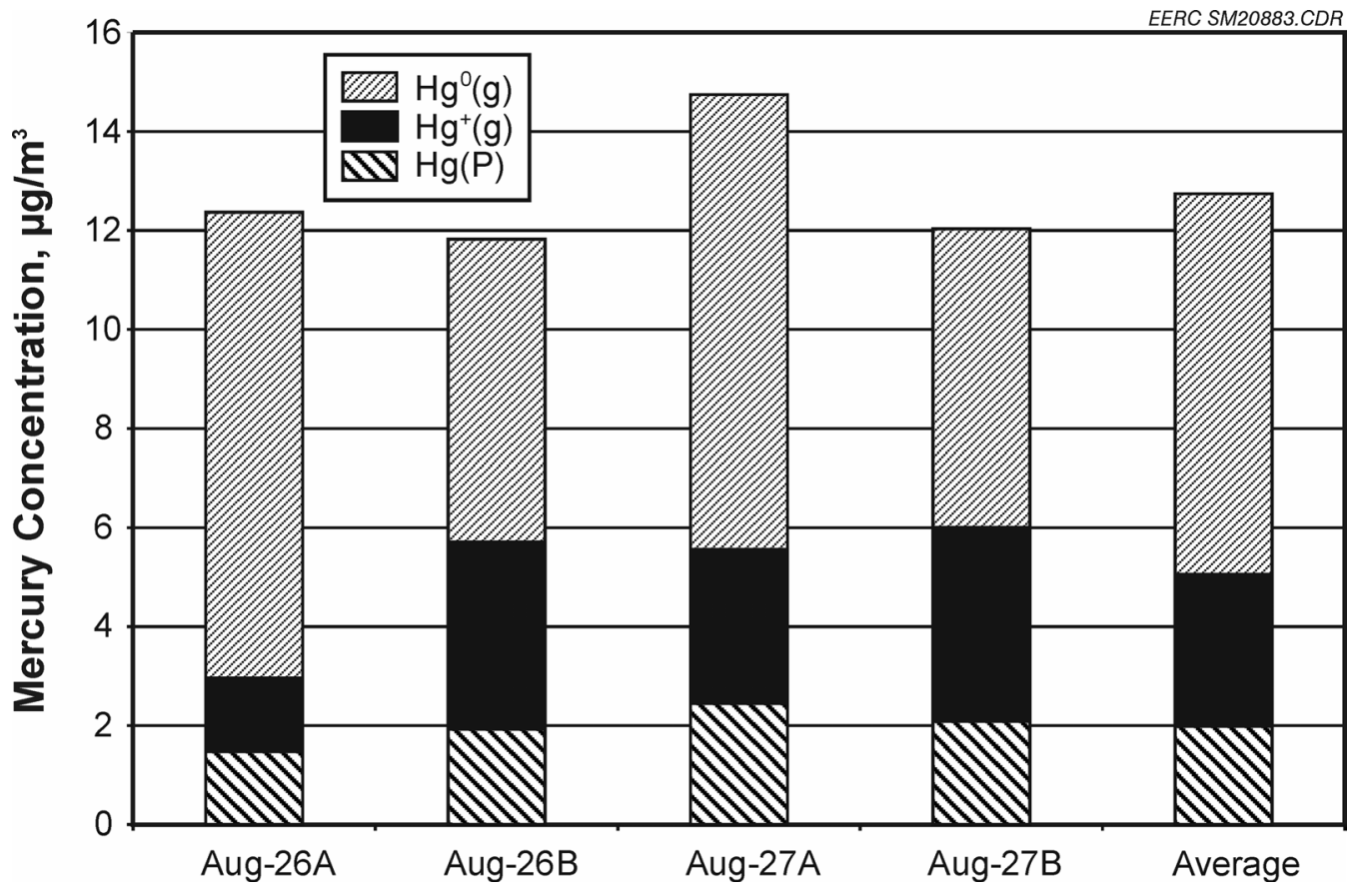

Figure 2. Inlet mercury species distributions for the AHPC at Big Stone, August 26-27. 


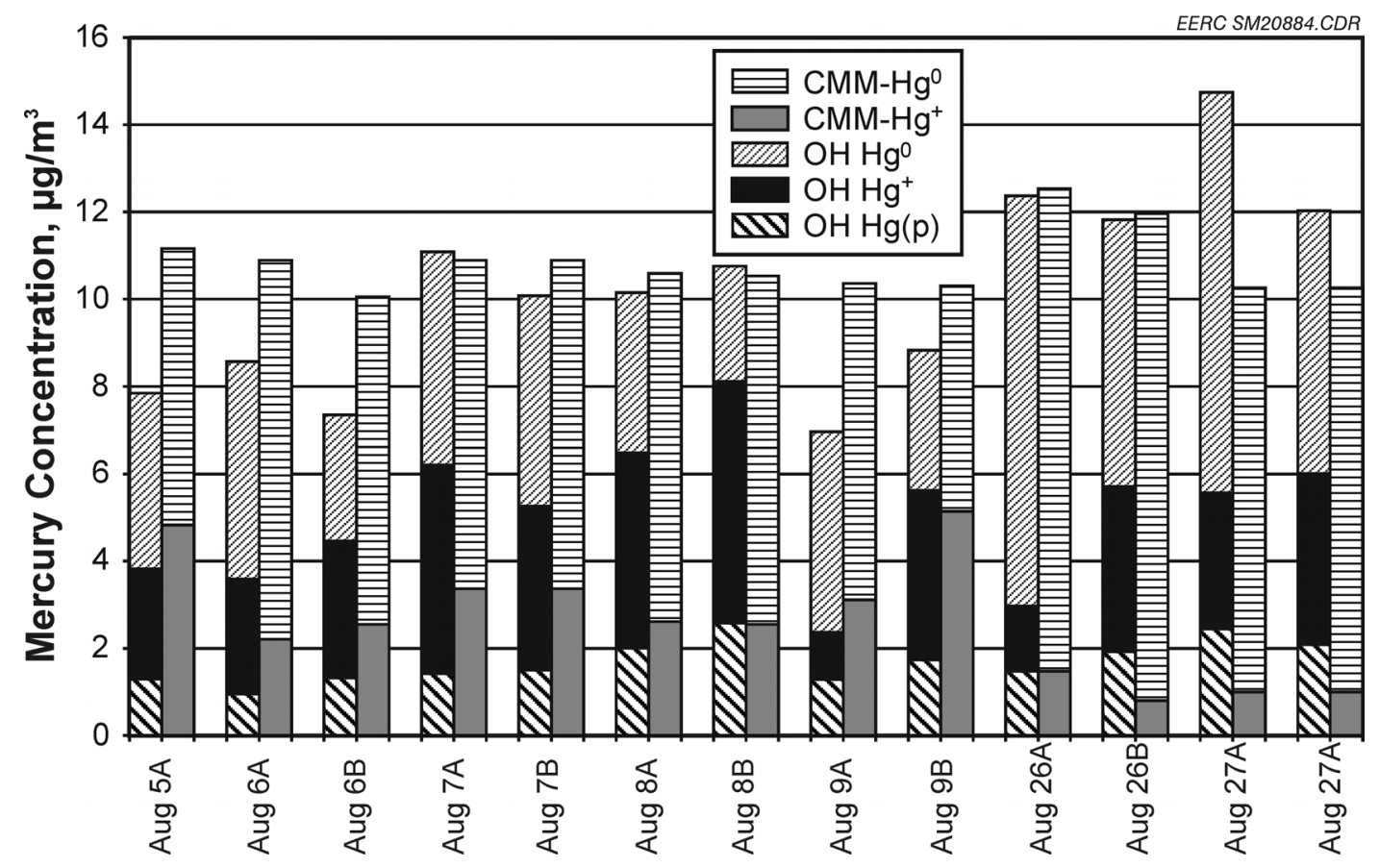

Figure 3. Summary of mercury species at the AHPC inlet from August to September 2002 (Ontario Hydro and CMM results).

to minimize any gas-particulate contact. In contrast, the Ontario Hydro samples are collected isokinetically, and the particulate fraction is captured on a filter. The particulate mercury may have existed in the duct or have been absorbed on the particulate during sampling. Some of the particulate mercury in the Ontario Hydro method may be measured as vapor-phase mercury with the CMM. In spite of this difference, the CMM data, in most cases, are in good agreement with the Ontario Hydro data.

All of the CMM inlet data are given in Figure 4, showing total, elemental, and percent elemental. Inlet total mercury ranged from 8 to $14 \mu \mathrm{g} / \mathrm{m}^{3}$. Typically, the elemental mercury tracked the total and, with the exception of four data points, the fraction of elemental mercury was between $60 \%$ and $80 \%$. Comparing the mercury concentration when the two coals were burned (see Figure 4 and Table 5) does not indicate any clear effect of coal type beyond the dayto-day variability in the data.

The inlet mercury speciation may depend on a number of factors such as the amount of carbon in the fly ash, chlorine level in the coal, firing mode, contact with fly ash, and residence time. However, the current level of understanding of how these variables affect mercury speciation does not allow accurate prediction. In general, high-chlorine EB fuels tend to produce flue gas with more oxidized mercury and low-chlorine WSB coals tend to produce more elemental mercury. Data also show that contact between the fly ash and flue gas promotes mercury oxidation for some coals. 


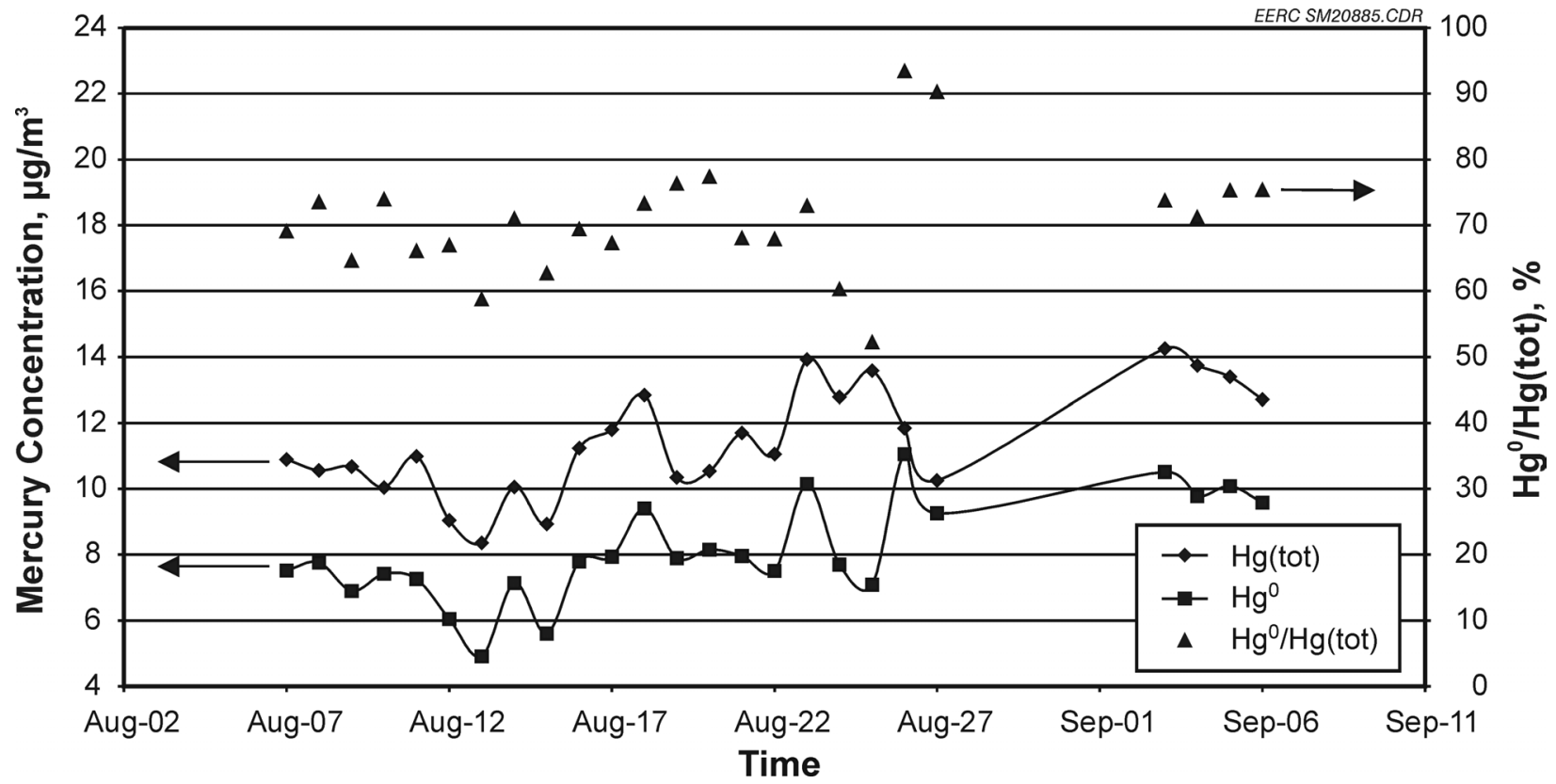

Figure 4. Daily average of inlet mercury species in flue gas at Big Stone (CMM data).

Figure 5 shows a comparison of inlet Ontario Hydro mercury speciation for the November 2001 field test, January 2002 EERC pilot-scale data burning the same fuel, EERC pilot-scale data burning the Belle Ayr coal from April to May, 2002, and August 5-9 and August 26-27, 2002, field test data with the Belle Ayr fuel. The error bars represent plus and minus one standard deviation.

Comparing inlet mercury speciation tests for the field tests completed in November and the baseline pilot-scale tests with the same Cordero coal reveals two significant differences. Even though the total values are similar within the margin of error, for the field results, an average of $56 \%$ of the mercury was retained by the fly ash compared to only $5 \%$ for the pilot-scale tests. A second significant difference is the vapor-phase speciation. For the field results, $38 \%$ of the inlet total was oxidized mercury, and only $6 \%$ was elemental mercury compared to $29 \%$ oxidized and $67 \%$ elemental for the pilot-scale tests.

A number of differences in conditions between the two tests could be responsible for the significant speciation difference. The $\mathrm{HCl}$ for the pilot-scale tests was measured by Method 26A to be 1-2 ppm in the flue gas compared to about $5 \mathrm{ppm}$ for the field test (Table 6). The additional $\mathrm{HCl}$ in the field tests is likely the result of the small percentage of waste tires that were cofired with coal at the Big Stone Power Plant during the November test. However, 5 ppm $\mathrm{HCl}$ is still a fairly low concentration compared to the 50-100 ppm level that is typically seen for bituminous coals. 


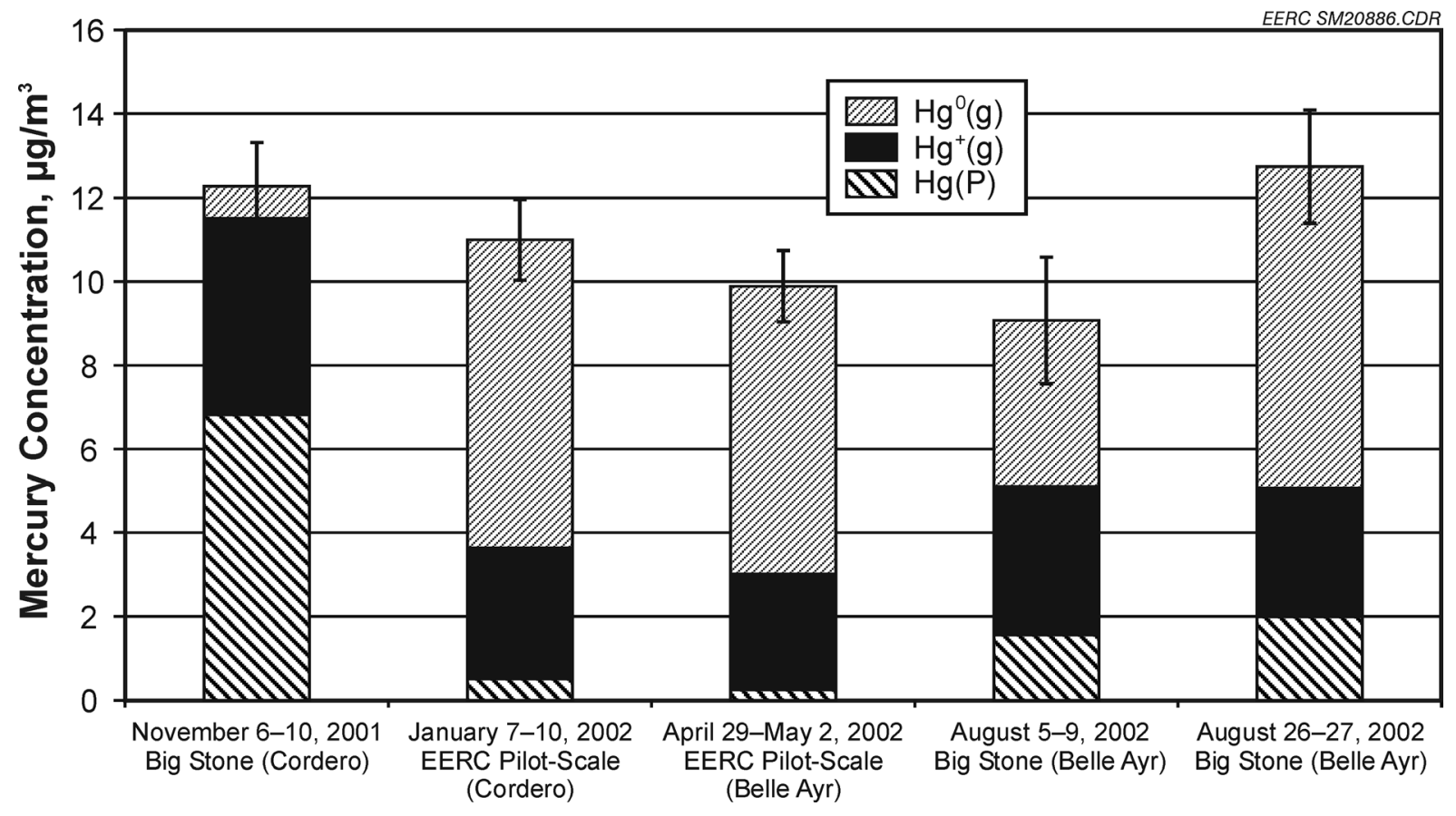

Figure 5. Comparison of mercury species distribution for the AHPC at the Big Stone Plant and EERC pilot-scale tests.

Table 6. Chlorine Concentration in Flue Gas at Big Stone Plant

\begin{tabular}{lc}
\hline Date & HCl, ppm \\
\hline November 7 & 4.3 \\
November 8 & 4.8 \\
November 9 & 4.7 \\
August 5 & 1.0 \\
August 7 & 0.9 \\
August 8 & 1.2 \\
August 26 & 0.5 \\
August 27 & 1.4 \\
August 28 & 1.2 \\
\hline
\end{tabular}

Another possible reason for the difference is the amount of unburned carbon in the ash, which for the Big Stone baseline tests ranged from $0.5 \%$ to $1.9 \%$ (without carbon injection) compared to only $0.16 \%$ for the pilot-scale tests. Under some conditions, carbon in the ash can be responsible for mercury retention and for promoting oxidation.

Cyclone firing is known to produce a finer fly ash particle size than pulverized-coal firing, which could also lead to more mercury retention as well as oxidation. Other work has shown that 
mercury concentration is typically higher in the smaller fly ash fraction, and the higher surface area of the finer particles may also promote more oxidation.

Comparing the EERC pilot-scale data between the Cordero and Belle Ayr coals (shown in Figure 5) suggests no difference as a result of coal type. The mercury speciation for the EERC pilot-scale tests with the Belle Ayr coal are also similar to the Big Stone field data with the same coal when TDF was not being cofired. However, the Big Stone data do show somewhat more particulate-bound mercury than the pilot-scale data. A possible reason for this difference is the slightly higher carbon content in the Big Stone ash.

The higher August 26-27 total mercury compared to the August 5-9 data is consistent with the CMM data and is likely due to somewhat higher mercury in the coal. The significant difference in mercury speciation between the August field data and the November field data, however, is likely the effect of cofiring the fuel with TDF, since the pilot-scale data indicated no difference between the two coals when they were burned without TDF.

\subsection{Baseline Mercury Capture Without Carbon Injection}

The Ontario Hydro data for baseline conditions are shown in Figure 6. Within experimental error, the total inlet and outlet mercury concentrations are the same, indicating no mercury capture. It does appear, however, that there is an increase in the fraction of oxidized mercury across the AHPC. Another baseline test was conducted August 19-20 while the plant was burning the Eagle Butte coal with a small amount of TDF. The CMM data for those tests

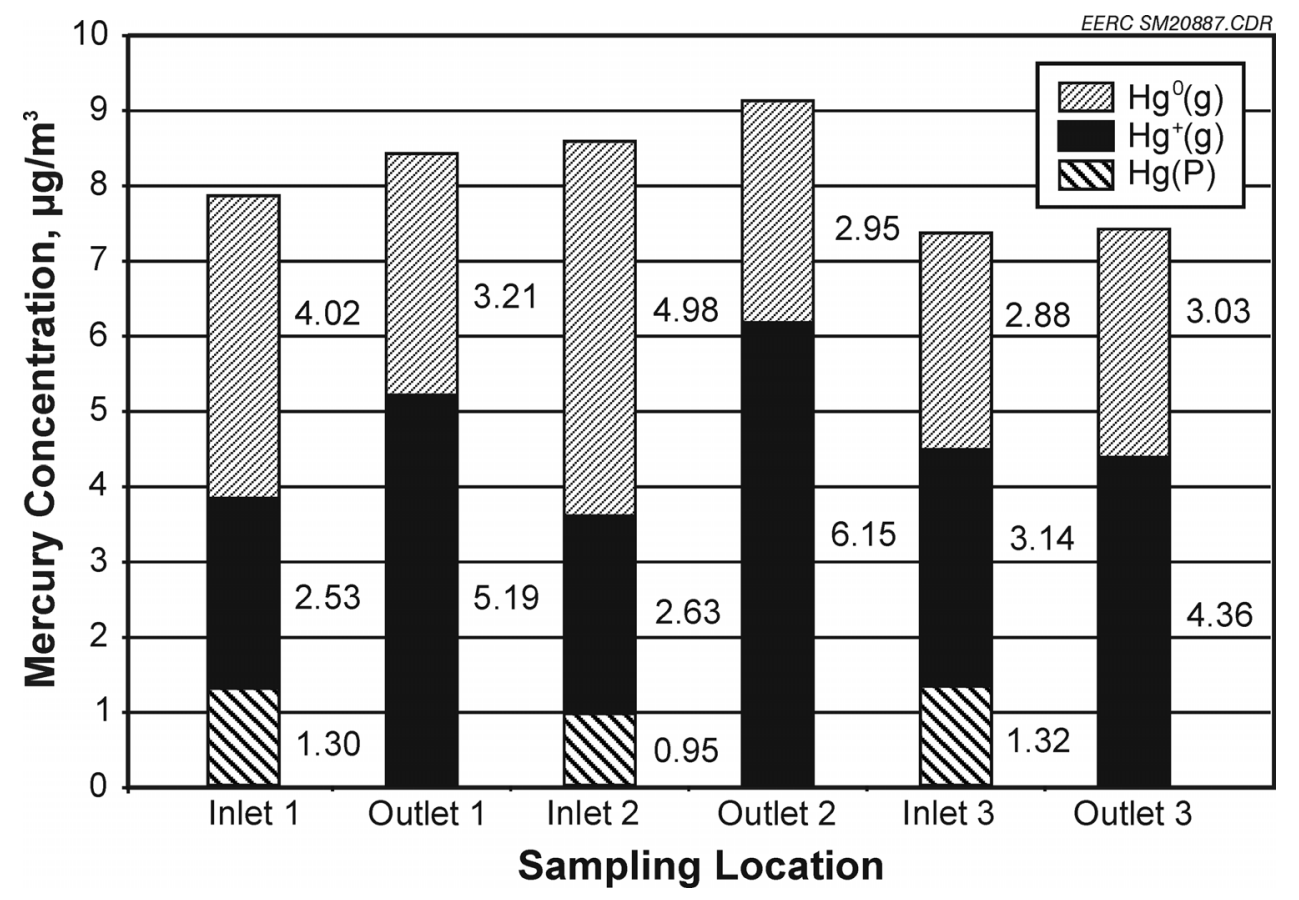

Figure 6. Inlet and outlet Ontario Hydro mercury speciation for the AHPC baseline test at Big Stone, August 5-6. 
indicated from $5 \%$ to $10 \%$ mercury capture without any carbon injection. Both of these baseline results are significantly different than the November tests with a much higher TDF cofiring rate, where $49 \%$ mercury capture was seen for the baseline conditions. Again, the most likely explanation is the much higher TDF cofiring rate and higher $\mathrm{HCl}$ in the flue gas for the November test.

\subsection{Carbon Injection Without TDF}

The carbon selected was the same DARCO FGD activated carbon that was used in the November field tests as well as the EERC pilot-scale tests. It is a commercially available sorbent produced by NORIT Americas. DARCO FGD powdered activated carbon is a lignite coal-base activated carbon manufactured specifically for the removal of heavy metals and other contaminants typically found in incinerator flue gas emission streams. It has a surface area of $600 \mathrm{~m}^{2} / \mathrm{g}$ and has been proven in numerous full-scale operating facilities to be highly effective for the removal of gaseous mercury, dioxins (PCDD) and furans (PCDF). Its open-pore structure and fine-particle size permit rapid adsorption, which is critical for high performance in flue gas streams where contact times are short.

The carbon was fed with a K-Tron dual-screw feeder at a starting rate of $24 \mathrm{~kg}$ of carbon sorbent/million $\mathrm{m}^{3}$ (1.5 lb of carbon sorbent/million acf), which corresponds to $0.29 \mathrm{~kg} / \mathrm{hr}$ $(0.65 \mathrm{lb} / \mathrm{hr})$ at an air-to-cloth $(\mathrm{A} / \mathrm{C})$ ratio of $3.0 \mathrm{~m} / \mathrm{min}(10 \mathrm{ft} / \mathrm{min})$. This is equivalent to a carbonto -mercury ratio of 3000:1 for an inlet mercury concentration of $14 \mu \mathrm{g} / \mathrm{m}^{3}$. The carbon feeder was located in the enclosed area of the AHPC below the hopper. From the screw feeder, the carbon was introduced into an Air-Vac eductor that was driven by compressed air. From the outlet of the eductor, the carbon was then transported approximately $6.1 \mathrm{~m}(20 \mathrm{ft})$ through $0.019-\mathrm{m}(0.75$-in.) stainless steel tubing to the elbow location of the inlet piping. Approximately $0.9 \mathrm{~m}(3 \mathrm{ft})$ of straight tubing extended inside the duct so that the carbon was injected directly upstream at a single point in the center of the 0.610-m (24-in.)-diameter inlet pipe.

The feeder was calibrated prior to the start of carbon injection. In addition, the weight of carbon added during a day was divided by the time of injection to provide an average feed rate. According to the calibration data and weight-of-added-carbon data, the feeder appeared to provide a very steady and consistent feed rate within a few percent of the target rate. The carbon feed and injection system worked very well, and there were no problems with inconsistent feeding or plugging of the feeder or injection system. Other AHPC operating conditions are given in Table 7.

With no TDF cofiring on August 7, a sorbent injection test with a carbon feed ratio of 0.29 $\mathrm{kg} / \mathrm{hr}(0.65 \mathrm{lb} / \mathrm{hr})$ and a test where the feed ratio was doubled to $0.58 \mathrm{~kg} / \mathrm{hr}(1.28 \mathrm{lb} / \mathrm{hr})$ were completed. Both the Ontario Hydro and CMM results were in good agreement (Figure 7). At the lower feed rate of $0.29 \mathrm{~kg} / \mathrm{hr}(0.65 \mathrm{lb} / \mathrm{hr})$, mercury removal was $54 \%$, and at double the feed rate, it increased marginally to $61 \%$. Since doubling the carbon feed rate did not significantly improve mercury capture, the decision was made to do further testing at the lower carbon feed 
Table 7. Standard Operating Conditions During August 5-September 6, 2002

\begin{tabular}{lc}
\hline A/C Ratio & $10 \mathrm{ft} / \mathrm{min}(3 \mathrm{~m} / \mathrm{min})$ \\
Pulse Pressure & $70 \mathrm{psi}(482 \mathrm{kPa})$ \\
Pulse Duration & $200 \mathrm{~ms}$ \\
Pulse Sequence & $87654321($ multibank $)$ \\
Pulse Trigger & $8.0 \mathrm{in} . \mathrm{W} . \mathrm{C} .(2.0 \mathrm{kPa})$ \\
Pulse Interval & $260-400 \mathrm{~min}$ \\
Temperature & $127^{\circ}-160^{\circ} \mathrm{C}\left(260^{\circ}-320^{\circ} \mathrm{F}\right)$ \\
Rapping Interval & $15-20 \mathrm{~min}$ \\
Voltage & $58-62 \mathrm{kV}$ \\
Current & $55 \mathrm{~mA}$ \\
\hline
\end{tabular}

rate. Two additional Ontario Hydro tests were completed at $0.29 \mathrm{~kg} / \mathrm{hr}(0.65 \mathrm{lb} / \mathrm{hr})$ on August 8 (Figure 8). Again, the Ontario Hydro and CMM results were in good agreement and indicated 63\%-68\% removal, slightly better than the August 7 test. On August 9, two more pairs of Ontario Hydro samples were taken at a $0.29 \mathrm{~kg} / \mathrm{hr}(0.65 \mathrm{lb} / \mathrm{hr})$ carbon injection rate. The removal efficiency for the two Ontario Hydro results, as well as for the previous three tests, are shown in Figure 9. The average removal efficiency for the five tests was $63.1 \%$.

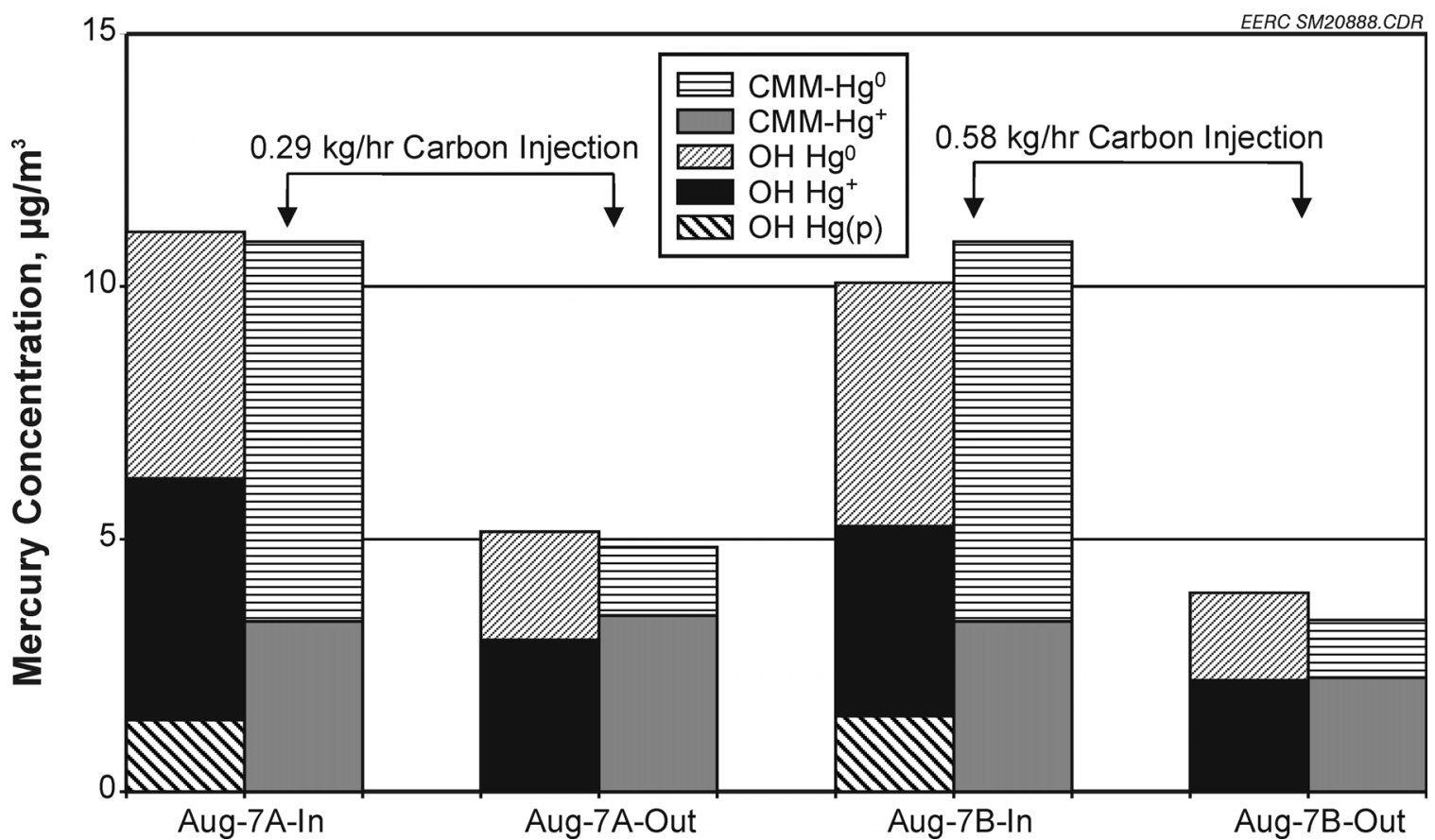

Figure 7. Mercury species concentration in flue gas at the AHPC inlet and outlet at two different carbon injection rates. 


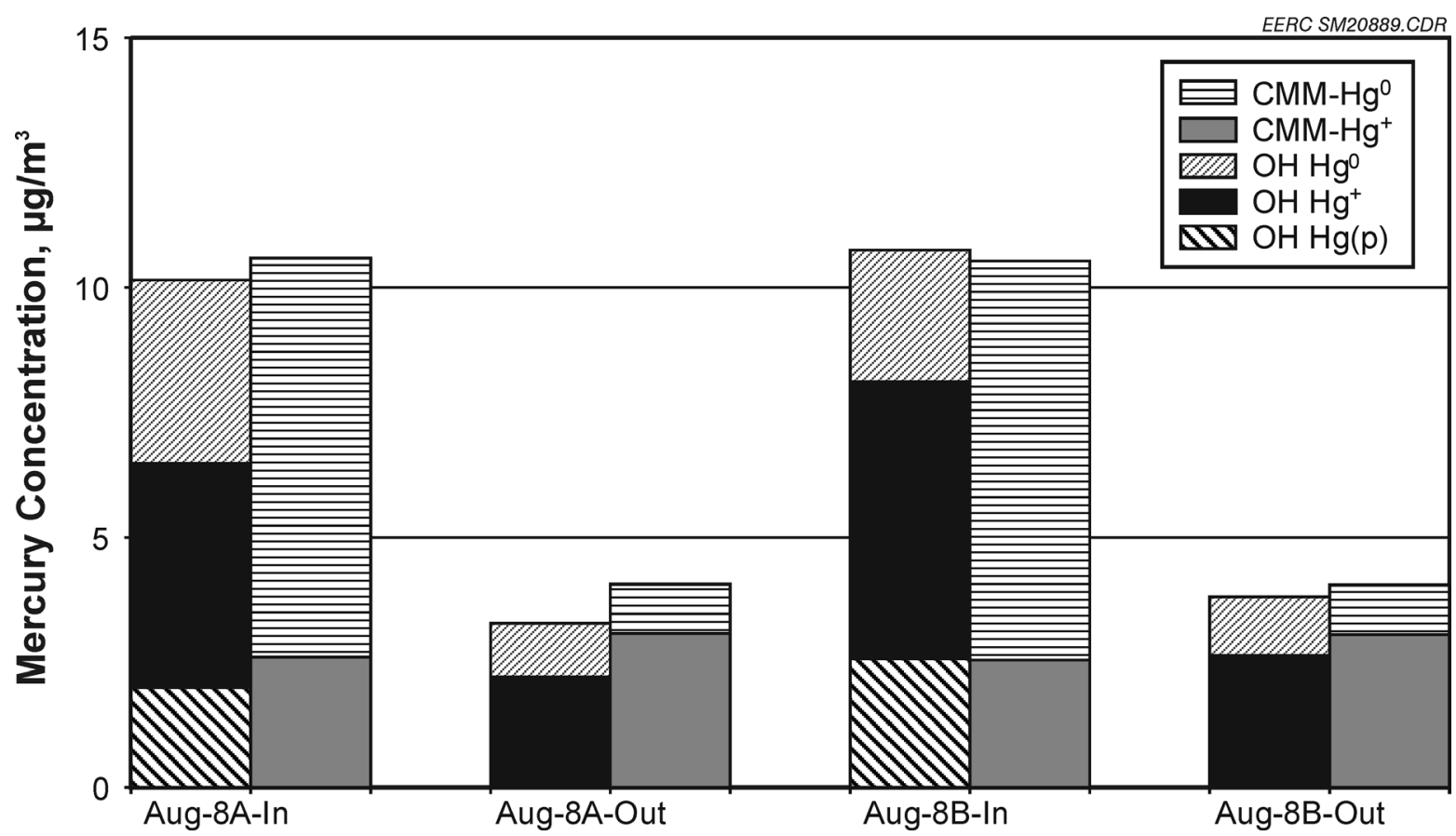

Figure 8. August 8 mercury species concentration in flue gas at the AHPC inlet and outlet at $0.29 \mathrm{~kg} / \mathrm{hr}$ carbon injection.

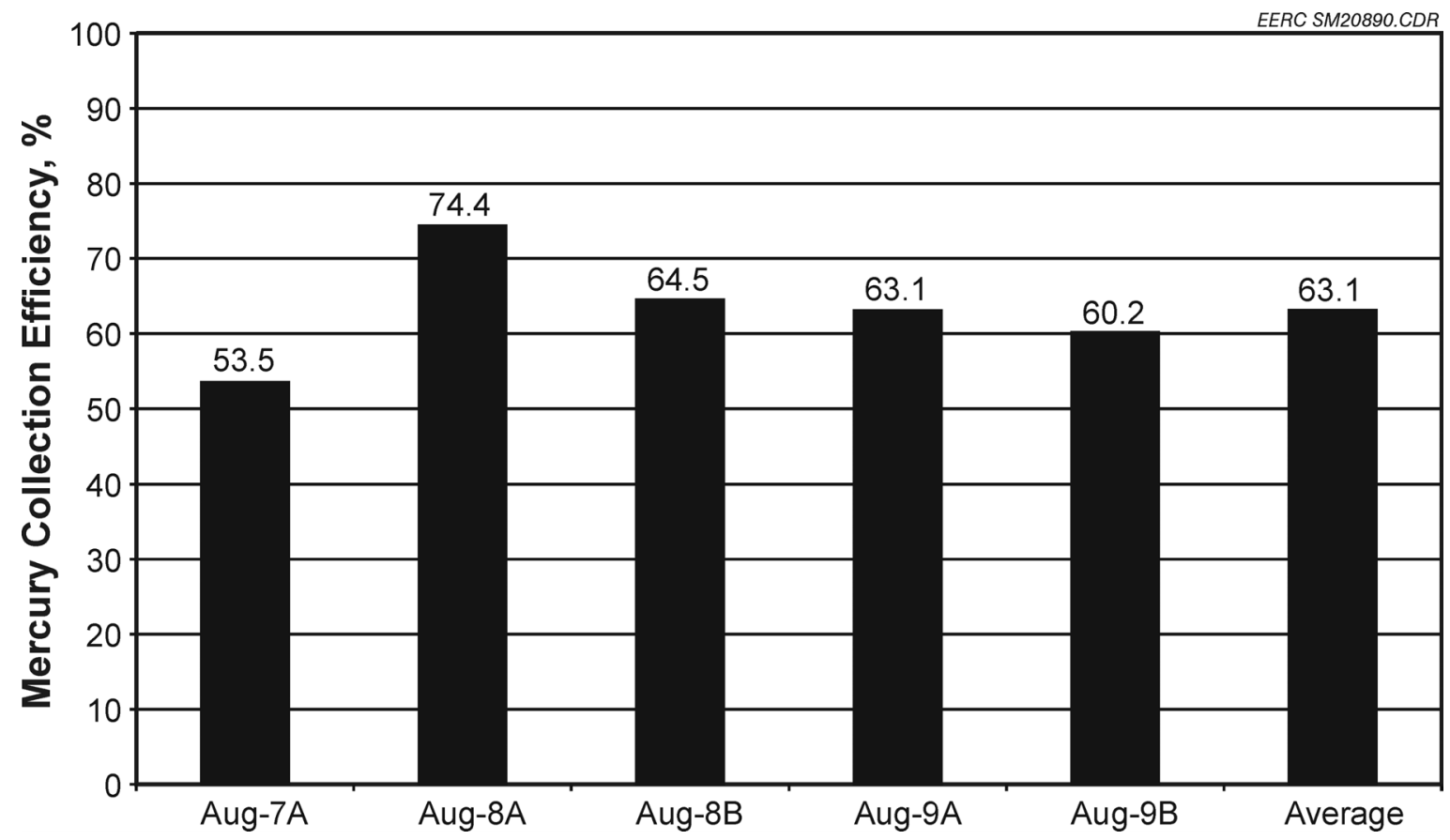

Figure 9. Overall mercury collection efficiency at $0.29 \mathrm{~kg} / \mathrm{hr}$ carbon injection, August 7-9. 
This is lower than the $91 \%$ removal seen last November but similar to the $50 \%-60 \%$ removal seen with EERC pilot-scale tests completed earlier this year $(1,4)$. This suggests that the higher removal seen last November was because of the much higher TDF feed rate and higher $\mathrm{HCl}$ in the flue gas. Two additional tests were completed on August 26 with the lower carbon feed rate and without any TDF cofiring. These results along with the previous results when both Ontario Hydro and CMM data were available are shown in Figure 10. With the exception of the August 9 data, the Ontario Hydro and CMM data are in excellent agreement. This provides confidence that the CMM data for the rest of the month are reliable when Ontario Hydro samples were not taken. From these results, it appears that a fairly low carbon addition rate of $0.29 \mathrm{~kg} / \mathrm{hr}$ (which is equivalent to $1.5 \mathrm{lb} / \mathrm{million}$ acf) can provide from $60 \%$ to $70 \%$ mercury control for the case without any TDF cofiring.

\subsection{Batch Injection Tests}

On August 27, a batch injection test was completed with high-voltage power on and another where the high voltage was briefly shut off during injection. For both tests, $0.91 \mathrm{~kg}$ $(2.0 \mathrm{lb})$ of carbon was injected in about 1 minute. The Ontario Hydro sampling was then started a half hour after injection for a period of $2 \mathrm{hr}$. CMM data were also taken during this time. The inlet and outlet mercury speciation results along with the continuous injection tests completed the previous day at $0.29 \mathrm{~kg} / \mathrm{hr}(0.65 \mathrm{lb} / \mathrm{hr})$ are shown in Figures 11 and 12. The data indicate that the batch power-on removal is comparable to the continuous injection results, but the power-off batch injection improved the collection efficiency to $82.5 \%$. This suggests that it might be possible to optimize the overall collection efficiency by modifying the injection approach.

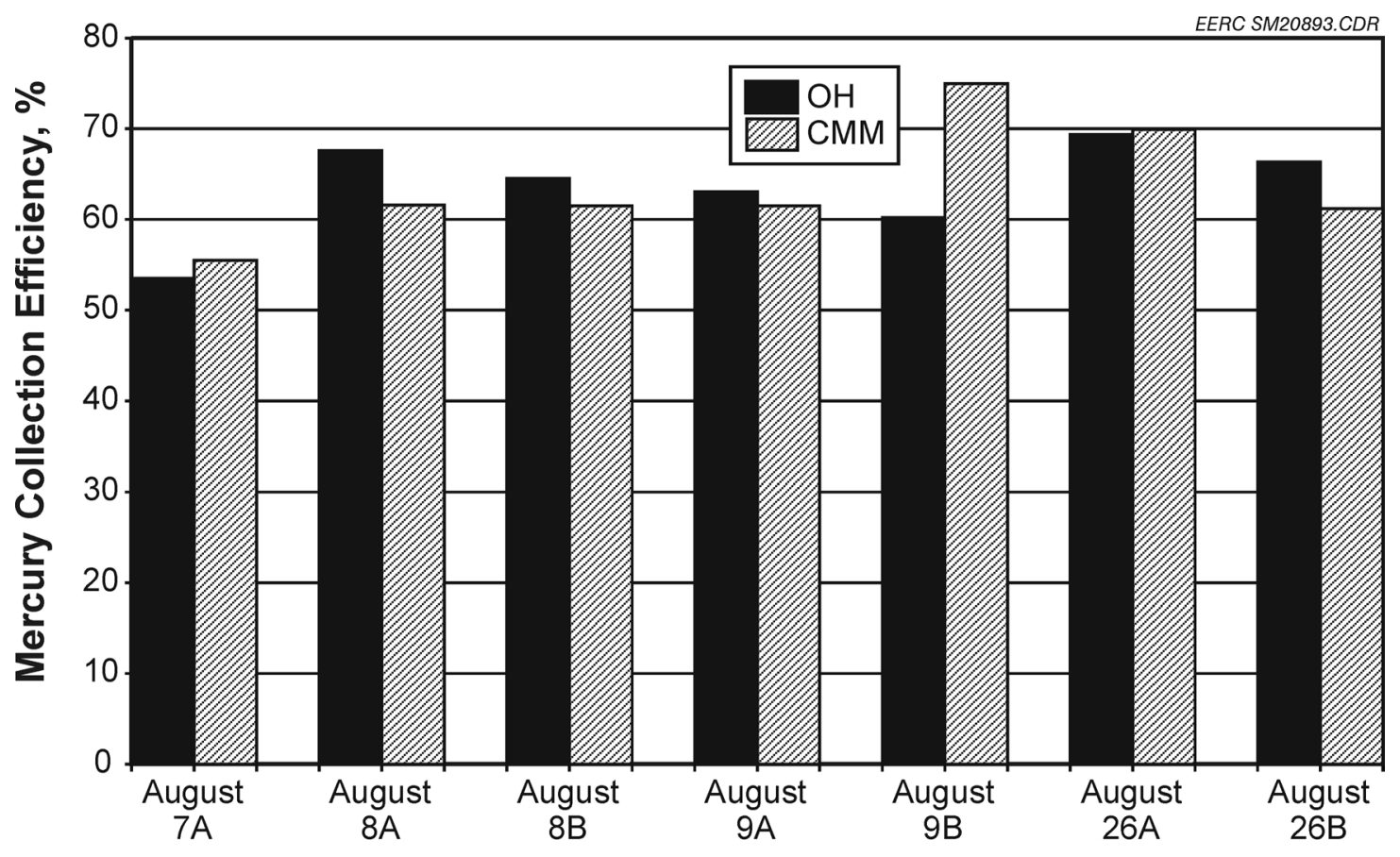

Figure 10. Ontario Hydro and CMM measurements of collection efficiency by the $\mathrm{AHPC}$ at $0.29 \mathrm{~kg} / \mathrm{hr}$ carbon injection. 
However, on a larger scale, batch injection would likely not be as practical as continuous injection. Another batch injection test was completed where the batch amount was increased to $1.82 \mathrm{~kg}(4.0 \mathrm{lb})$ with only the CMM measurement. In this case, the outlet mercury was near zero for over $2 \mathrm{hr}$ before it slowly started to increase, and even after $3 \mathrm{hr}$, the integrated average removal was over $90 \%$. This implies that all of the flue gas was effectively treated and that with a reactive sorbent, it should be possible to achieve over $90 \%$ mercury removal.

\subsection{Effect of Supplemental TDF on Mercury Removal}

TDF cofiring was started August 12, but at a much lower rate than the 90-250 ton/day rate during the November test (see Table 5). Subsequently, the effect on mercury removal was small. From the daily averages of the CMM data for the entire month, shown in Figure 13, it does appear that mercury removal improved from about $63 \%$ on August $9-11$ to about $68 \%$ on August 12-13. On August 14 and part of the day on August 15, the carbon feed rate was doubled to $0.58 \mathrm{~kg} / \mathrm{hr}(1.28 \mathrm{lb} / \mathrm{hr})$. At the higher rate on the $14 \mathrm{th}$, the removal increased to $77 \%$, and on the 15 th, it reached $89 \%$. However, the $89 \%$ removal corresponded to a time of lower plant load where the temperature was about $11^{\circ} \mathrm{C}\left(20^{\circ} \mathrm{F}\right)$ lower than normal. Later on the 15 th, the carbon feed rate was reduced back to $0.29 \mathrm{~kg} / \mathrm{hr}(0.65 \mathrm{lb} / \mathrm{hr})$, and with a temperature increase, the removal dropped to $69 \%$. This is consistent with the data from August 12-13 and suggests that the small rate of TDF cofiring resulted in some improvement in mercury collection.

From August 16 to 18, the TDF was stopped again, but the plant switched fuel to the Eagle Butte, so the coal switch may have also affected the mercury removal with carbon injection. Without TDF, the removal ranged from $66 \%$ to $73 \%$ at a carbon addition rate of $0.29 \mathrm{~kg} / \mathrm{hr}$ $(0.65 \mathrm{lb} / \mathrm{hr})$. Since no baseline data were available without carbon with the Eagle Butte coal, the carbon was stopped on August 19-20. The resulting removal was in the range of only 5\%-10\%, so the small carbon addition rate appeared to be reasonably effective. On August 20-22, the high-voltage power supply current was decreased to $25 \mathrm{~mA}$ from the standard condition of $55 \mathrm{~mA}$. The data from Figure 13 indicate the mercury removal improved to $84 \%-88 \%$ during this time. However, this corresponded to the only 2 days when the TDF was high. At the time of the tests, the amount of TDF was unknown. The next day on August 23 when the TDF was stopped, the mercury removal was $76 \%$. This indicates that the $84 \%-88 \%$ removal seen the previous 2 days was partly due to the higher TDF rate.

\subsection{Effect of Current on Mercury Removal}

Reducing the current is expected to increase the amount of carbon that reaches the bags and subsequently produce better gas-sorbent contact. A closer examination of the immediate effect of a change in current is shown in the CMM data from August 21-23 (Figure 14). During this time, the highest TDF feed rate was seen, but whenever the current was changed, there was an immediate effect. On August 21 at 12:00, the change in current resulted in an immediate decrease in outlet mercury concentration from 2.3 to $1.7 \mu \mathrm{g} / \mathrm{m}^{3}$; on August 22 at noon, a current 


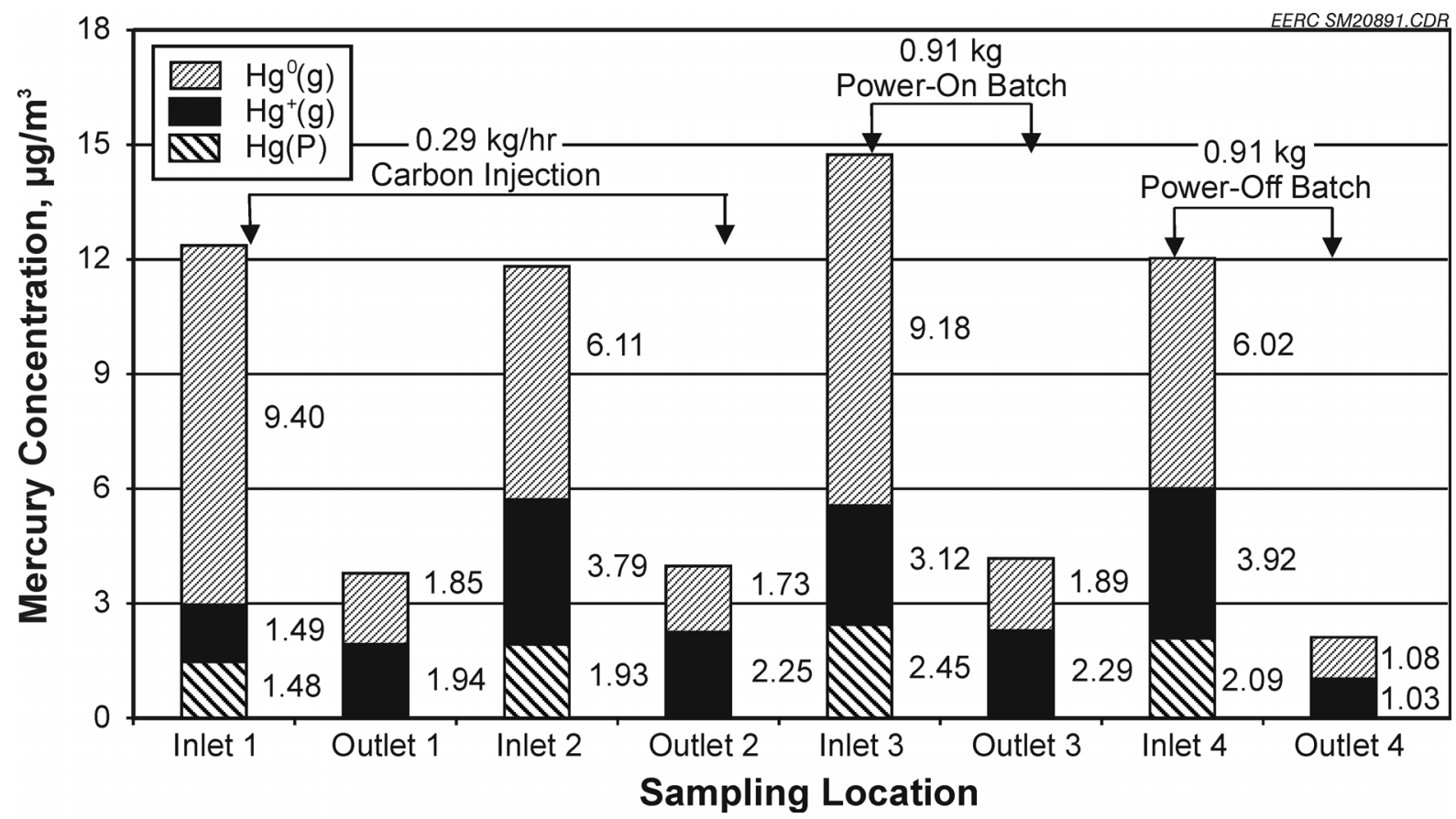

Figure 11. Mercury species concentration in flue gas at the AHPC inlet and outlet for continuous and batch carbon injection, August 26-27.

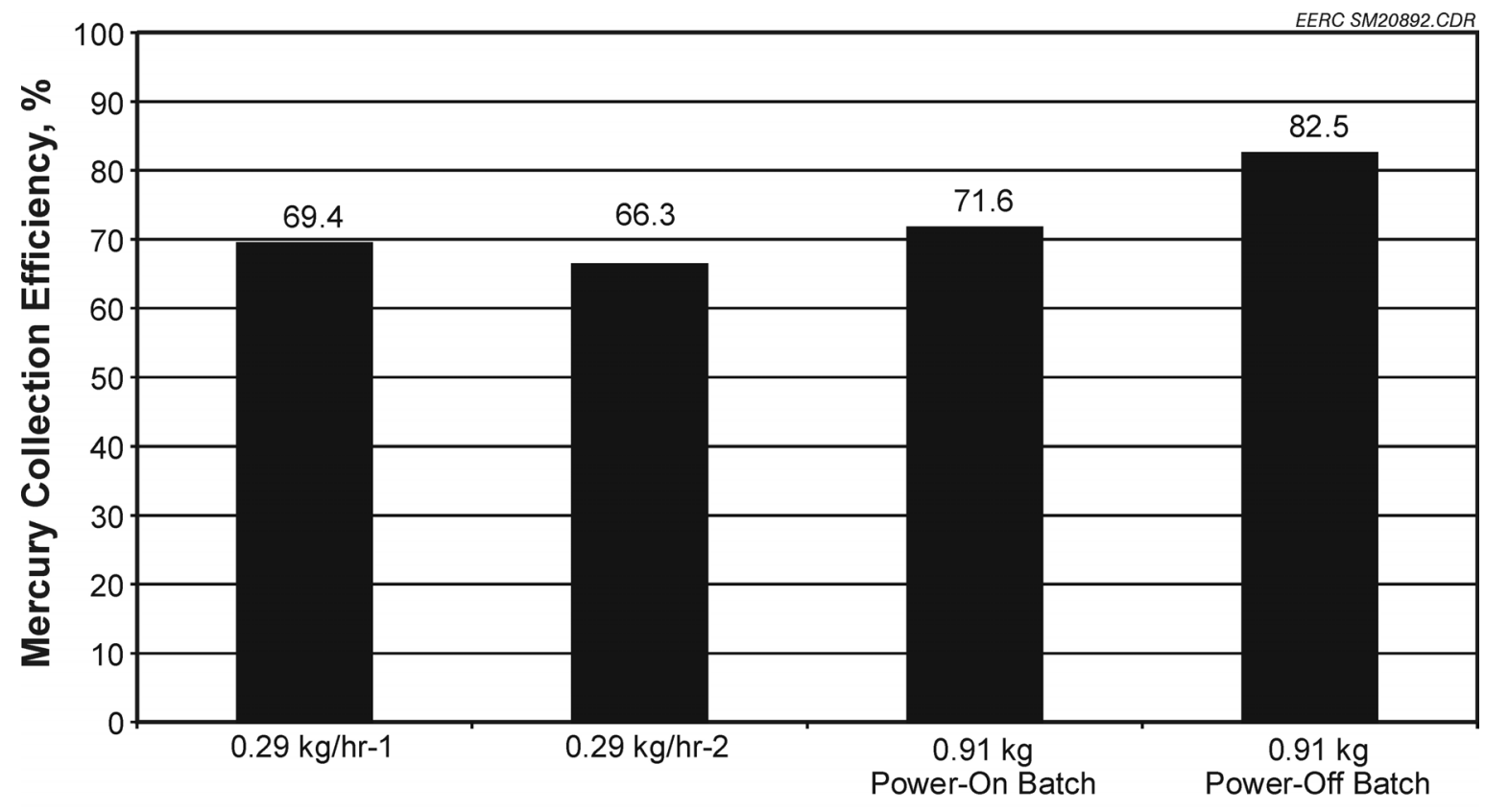

Carbon Injection Mode

Figure 12. Mercury collection efficiency for continuous and batch carbon injection tests, August 26-27. 


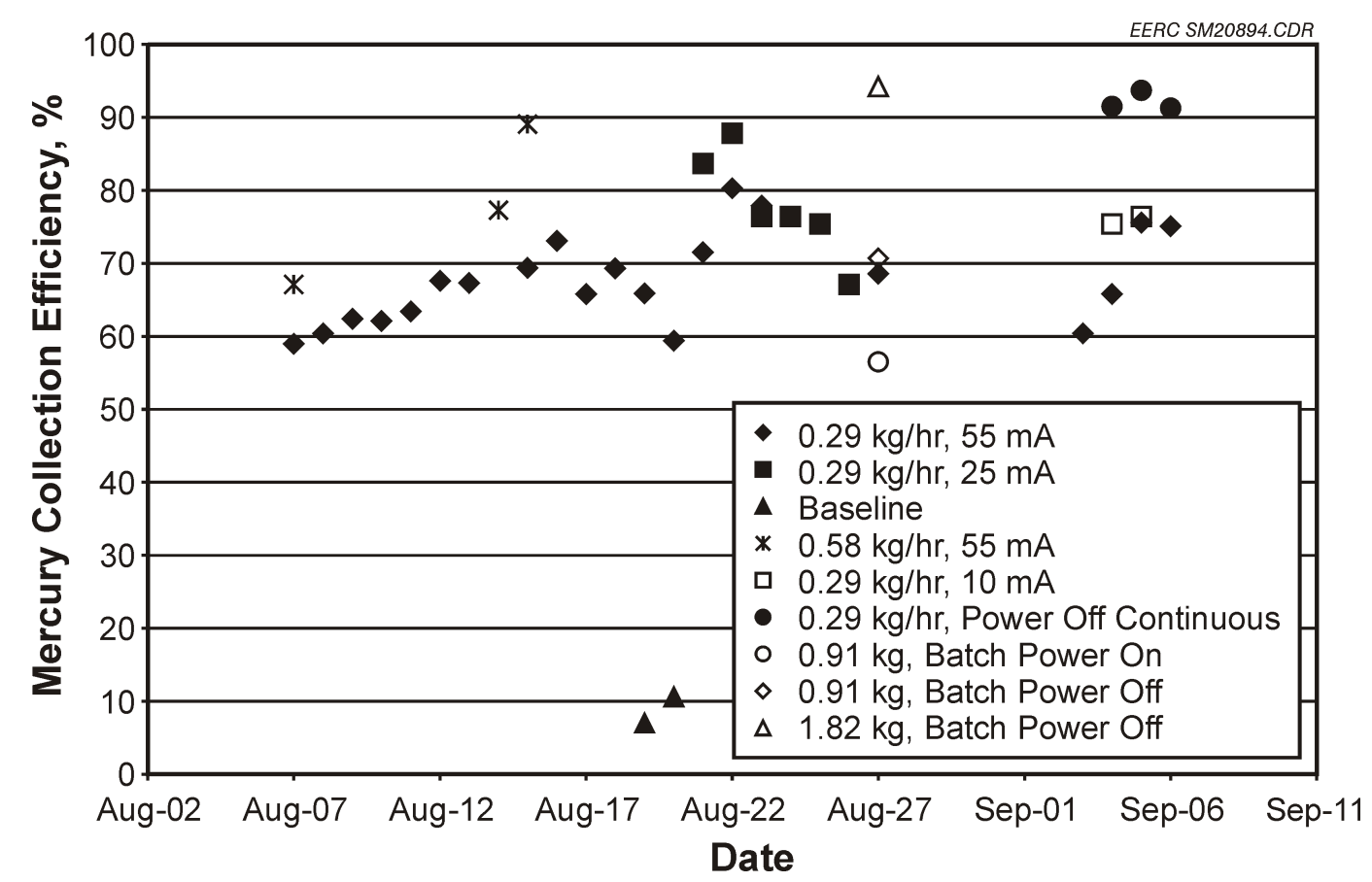

Figure 13. Total mercury vapor capture efficiency at Big Stone during the August-September test (CMM data).

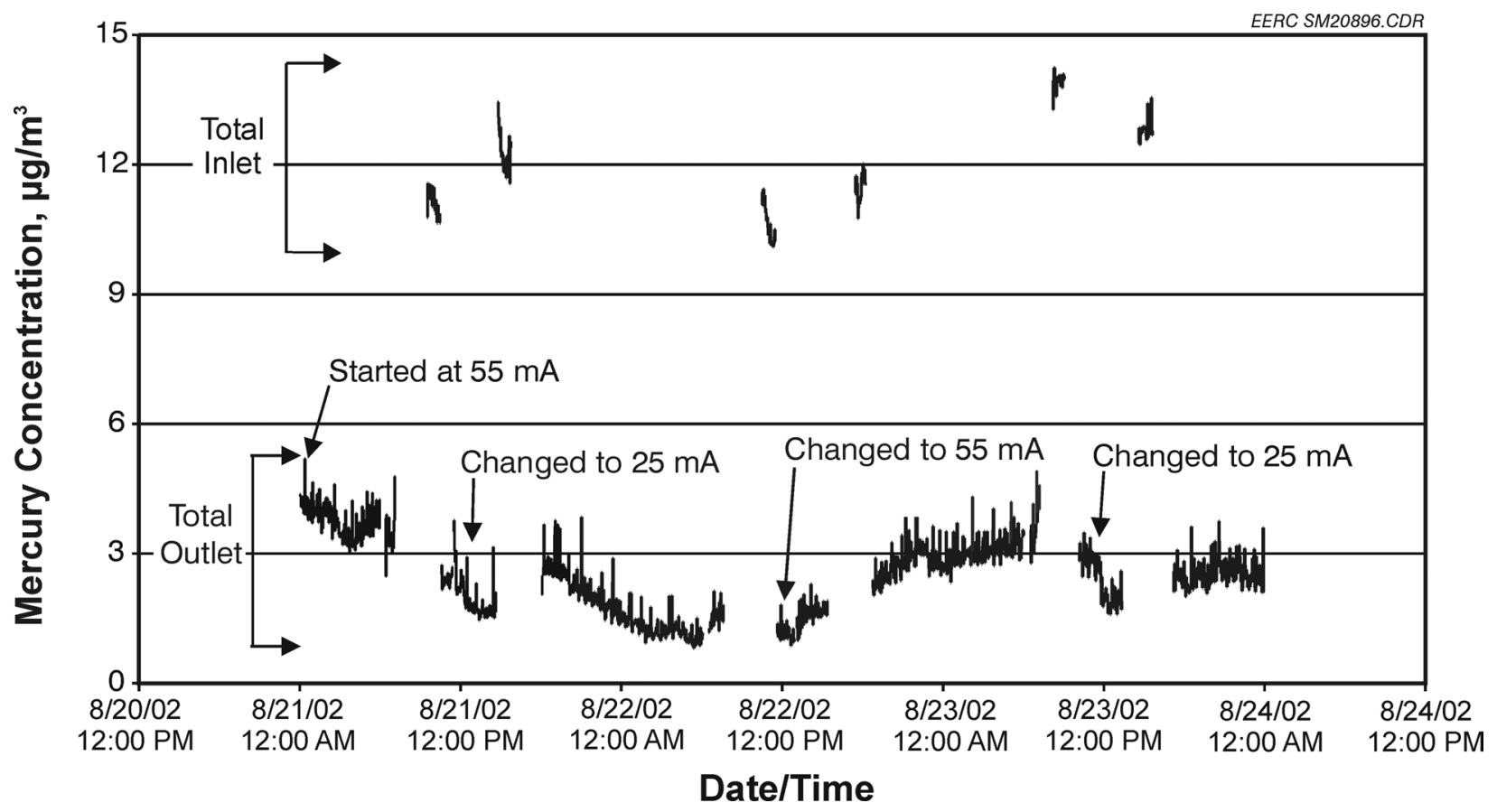

Figure 14. Inlet and outlet mercury CMM data, August 21-23. 
increase from 25 to $55 \mathrm{~mA}$ resulted in an increase in mercury from 1.2 to $1.7 \mu \mathrm{g} / \mathrm{m}^{3}$; and on August 23 at noon, a current change back to $25 \mathrm{~mA}$ resulted in a decrease in mercury from 2.9 to $2.0 \mu \mathrm{g} / \mathrm{m}^{3}$. These data indicate that somewhat better mercury removal might be achieved by reducing the current. Operational data indicate that there would be some compromise in AHPC performance, because at the $25 \mathrm{~mA}$ setting the bags needed to be pulsed every $150 \mathrm{~min}$ compared to about $300 \mathrm{~min}$ at $55 \mathrm{~mA}$. However, in both cases, the AHPC pressure drop was readily controlled at about $1.5 \mathrm{kPa}$ (6 in. W.C.).

\subsection{Power-Off Tests}

On September 5-6, several additional tests were completed where the current was reduced to $10 \mathrm{~mA}$ and, in the extreme case, shut off completely. The data show that the best removal was seen in short-term tests where the power was off (Figure 13). The effect on AHPC operation was a significant decrease in the pulse-cleaning requirement to $10 \mathrm{~min}$ (compared to $300 \mathrm{~min}$ at 55 $\mathrm{mA}$ ) and an increase in pressure drop. From past experience, pressure drop would not be controlled for long at these operating conditions. However, these results indicate that, in AHPC mode, the sorbent-gas contact may not be sufficient to achieve $90 \%$ removal at a low carbon addition rate. They also suggest that a modification to the pulse-cleaning sequence might improve mercury capture. Figure 15 shows individual bag flows for one row of the bags over several bag-cleaning cycles. Individual bag flow monitors were installed in the $1,3,5,7$, and 8 bag positions for one of the rows. The bags are numbered from the back of the unit to the front so bag number 8 is at the entrance of the AHPC where the dust loading is highest and number 1 is at the back where the dust loading is lowest. The data indicate that shortly after a pulse, the flows through the bags are similar or with power off, the flows are similar. However, in the operating mode when all of the bags are pulsed when the pressure drop reaches $2.0 \mathrm{kPa}(8 \mathrm{in}$. W.C.), a larger fraction of the flow goes through the last bags with increasing time from cleaning. Pulsing the bags more often or in a different sequence could significantly change the flow distribution, possibly resulting in better mercury capture. Future plans are to evaluate the effect of the pulse sequence on mercury control.

\subsection{Stack Mercury and Particulate Measurements}

In addition to the AHPC inlet and outlet Ontario Hydro mercury measurements, two samples were also taken at the midlevel of the Big Stone stack. The data shown in Figure 16 are similar to the AHPC inlet data (which are equivalent to the Big Stone ESP inlet) and would indicate little or no mercury removal across the ESP. The data also indicate little or no change in mercury speciation across the ESP.

As part of the Ontario Hydro measurements, the measured particulate level at the stack is given in Table 8. Based on inlet measurements from the AHPC inlet on the same day, the Big Stone collection efficiency is in the range from $99.75 \%$ to $99.77 \%$, which is well within compliance. However, because of the concentration of fine particles exiting the ESP, even at 


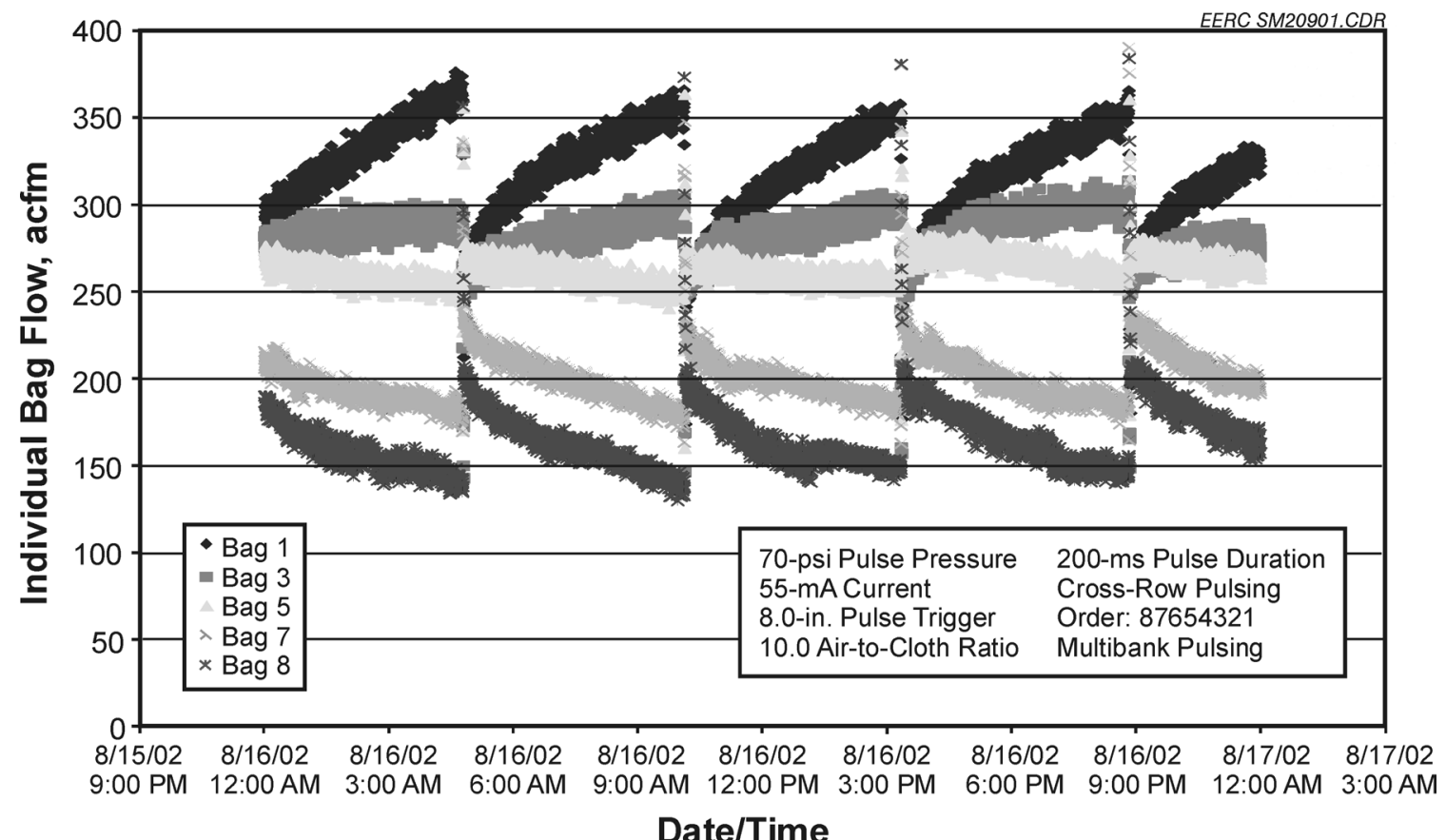

Figure 15. Individual bag flow rates for August 16.

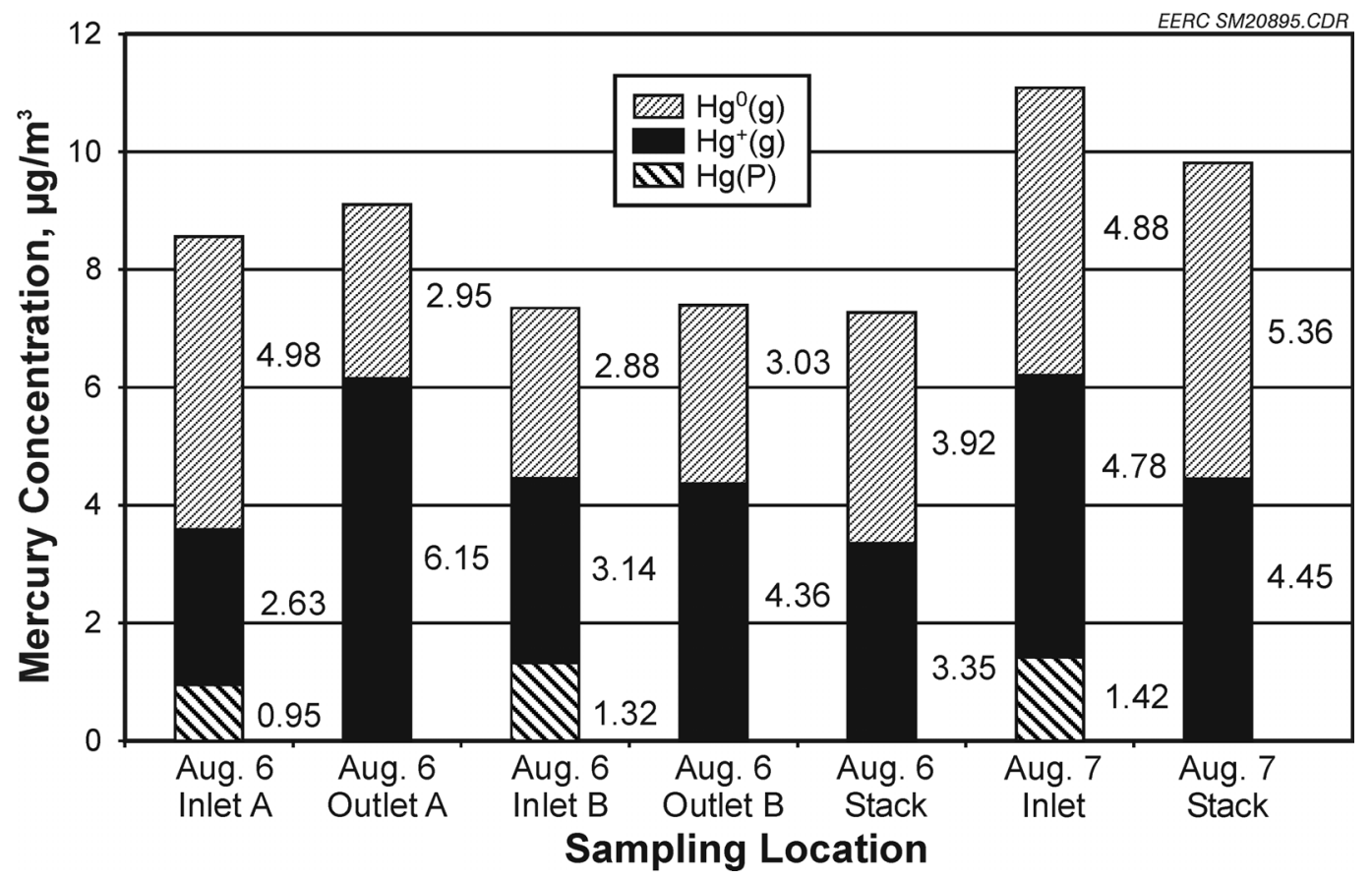

Figure 16. Mercury species in flue gas at the AHPC Big Stone stack. 
this level of control, a visible plume can frequently be seen at an opacity much less than the $20 \%$ opacity compliance requirement. These particulate emission values will serve as a baseline for comparison with emissions after the Big Stone Plant completes installation of a full-scale AHPC.

Table 8. Big Stone Plant Stack Emissions

\begin{tabular}{lcccc}
\hline Date & & $\begin{array}{c}\text { AHPC Inlet Dust } \\
\text { Loading, gr/scf }\end{array}$ & $\begin{array}{c}\text { Big Stone Stack } \\
\text { Dust Loading, gr/scf }\end{array}$ & $\begin{array}{c}\text { Big Stone ESP Collection } \\
\text { Efficiency, \% }\end{array}$ \\
\hline $8-6-02$ & Sample 1 & 0.9077 & & \\
& Sample 2 & 1.1308 & $0.0023^{*}$ & 99.774 \\
& Average & 1.0193 & & \\
$8-7-02$ & Sample 1 & 1.1981 & & \\
& Sample 2 & 1.1255 & $0.0029 *$ & 99.750 \\
\hline
\end{tabular}

* Single stack sample each day.

\subsection{Effect of Carbon Injection on AHPC Performance}

One of the main objectives of these tests was to assess the effect of carbon injection on longer-term AHPC performance. In order to achieve steady-state AHPC operation prior to starting carbon injection, the AHPC was started with new bags on June 28 and operated continuously until the start of the mercury tests in August. The pressure drop, bag-cleaning interval, $\mathrm{K}_{2} \mathrm{C}_{\mathrm{i}}$, and residual drag from June 28 until September 3 are shown in Figures 17-20. The daily average pressure drop data increase slightly with time as would be expected after starting with new bags. When the carbon was started on August 7, there was no perceptible change in pressure drop. The bag-cleaning interval was somewhat variable as a result of temperature and load swings, but, again there was no increase when the carbon feed was started. The $\mathrm{K}_{2} \mathrm{C}_{\mathrm{i}}$ values are an indication of the amount of dust that reaches the bags and subsequently relates to how well the ESP portion of the AHPC is working. Again, there was no perceptible change when the carbon was started. The residual drag data indicate how well the bags clean and also do not show any change as a result of the carbon.

Of interest is the effect on these performance parameters with the lower current setting of $25 \mathrm{~mA}$ (see Figures 17-20). At $25 \mathrm{~mA}$, the bag-cleaning interval drops to about one-half, and the $\mathrm{K}_{2} \mathrm{C}_{\mathrm{i}}$ value approximately doubles. Both of these indicate that about twice as much dust reaches the bags at $25 \mathrm{~mA}$ compared to $55 \mathrm{~mA}$. However, almost no effect on pressure drop or residual drag was seen. This implies that it should be possible to optimize AHPC operational parameters to get the best overall mercury removal while maintaining good AHPC performance. 


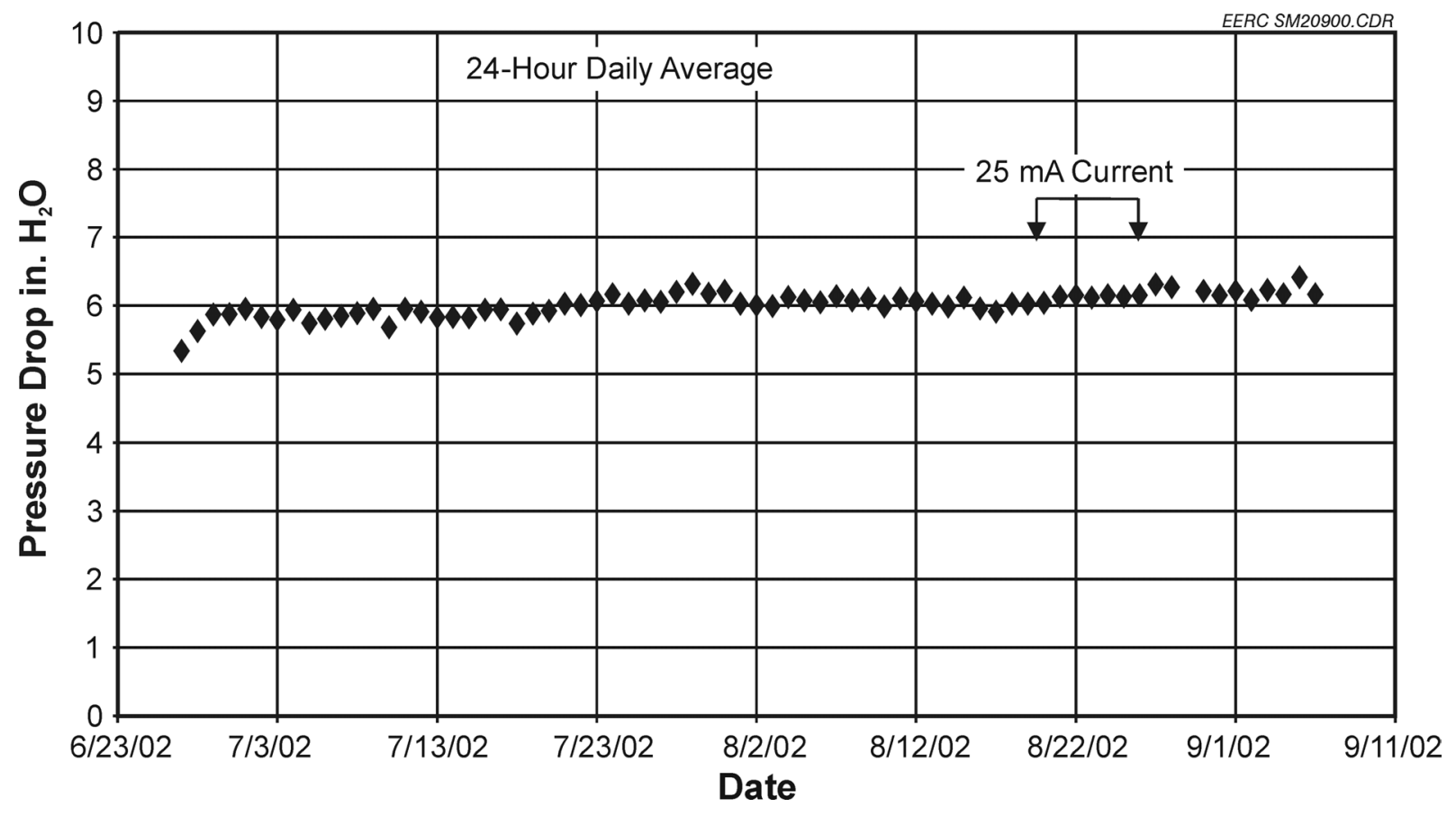

Figure 17. Average daily pressure drop for June 28-September 3.

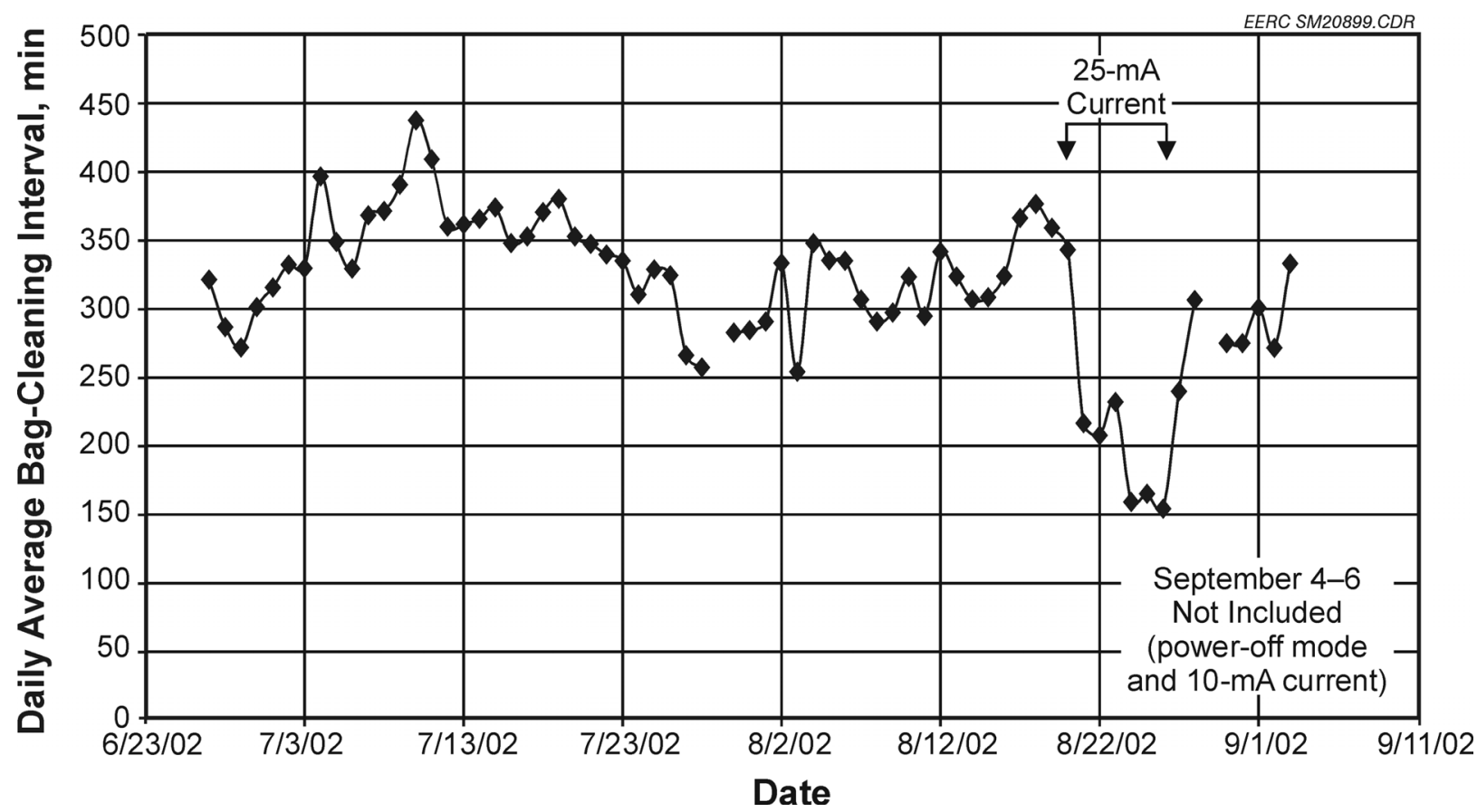

Figure 18. Daily average bag-cleaning interval for June 28-September 3. 


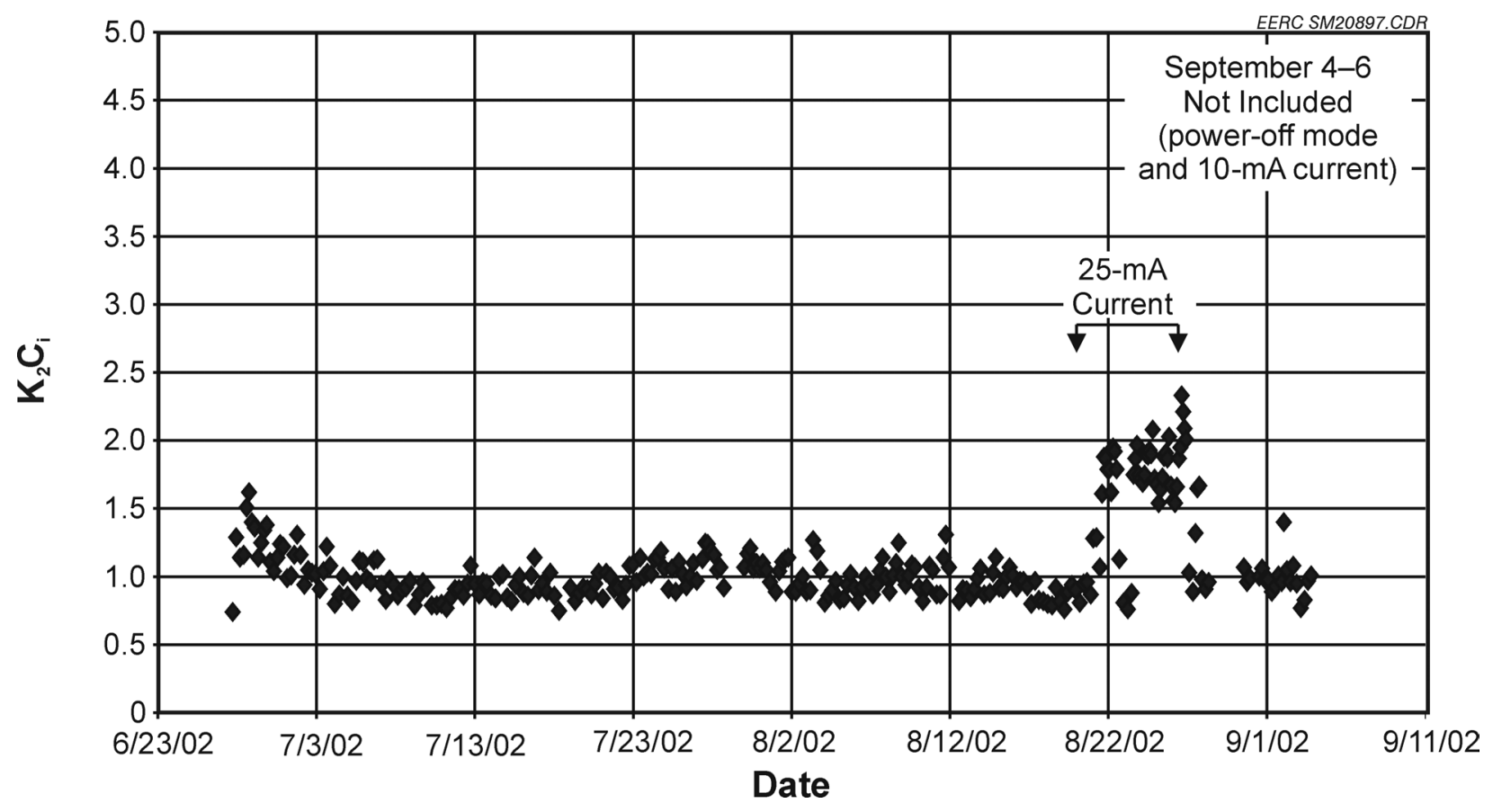

Figure 19. Overall $\mathrm{K}_{2} \mathrm{C}_{\mathrm{i}}$ for June 28-September 3.

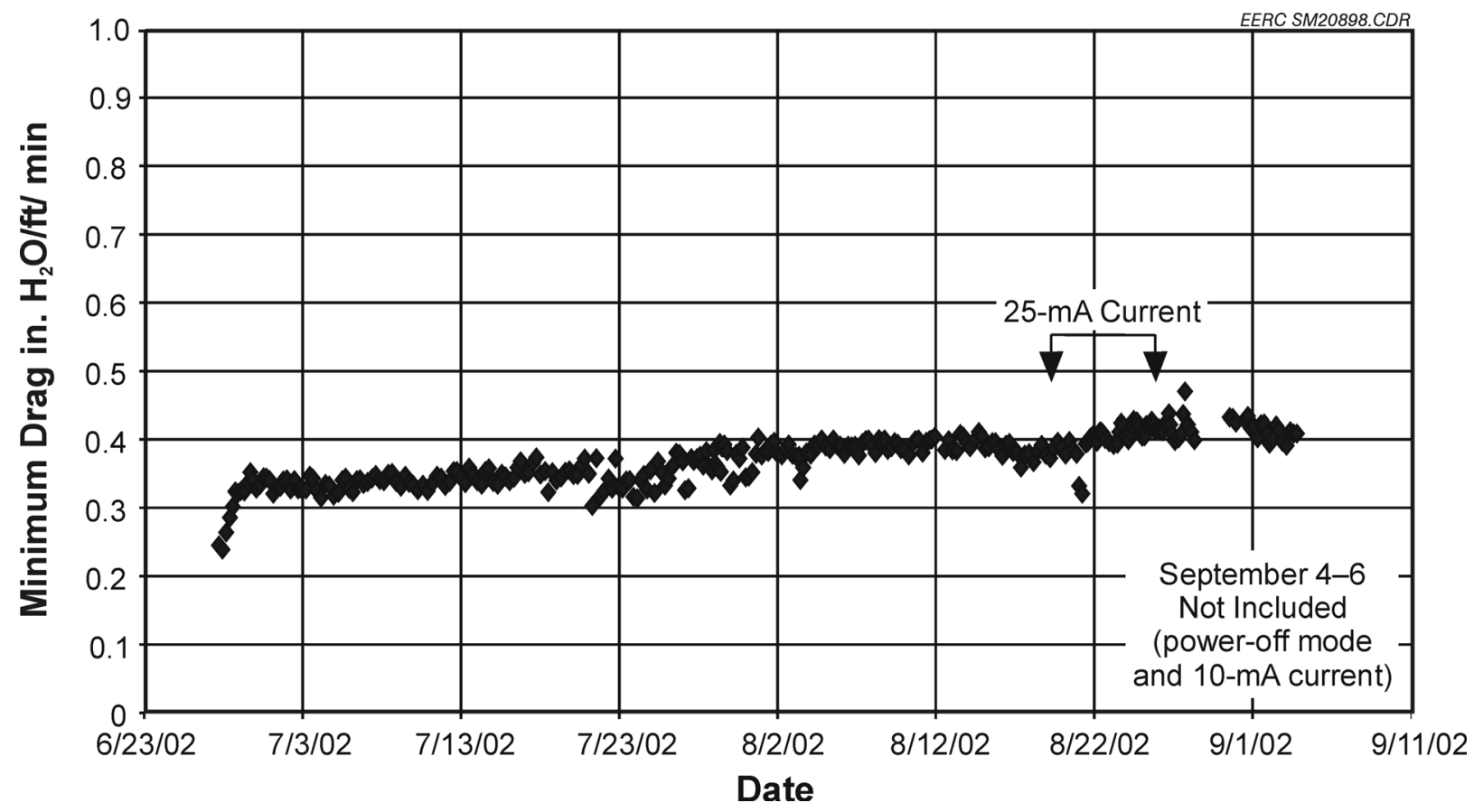

Figure 20. Overall minimum drag for June 28-September 3. 


\subsection{CONCLUSIONS}

- The average inlet mercury speciation from the November 2001 field test was $55.4 \%$ particulate-bound, $38.1 \%$ oxidized, and $6.4 \%$ elemental. This high level of particulate-bound mercury and oxidized mercury was somewhat surprising because, for western PRB coals, lower levels of particulate-bound mercury and oxidized mercury are more typical. The inlet speciation during the August 2002 tests averaged 17\% particulate-bound, 32\% oxidized, and $51 \%$ elemental. The significant difference in mercury speciation between the August field data and the November field data is likely the effect of a higher rate of cofiring of the coal with TDF during the November test.

- In the November tests, $49 \%$ mercury capture was seen for the baseline conditions without carbon injection. The August tests indicated only from $0 \%$ to $10 \%$ mercury capture with no carbon injection. Again, the most likely explanation is the much higher TDF cofiring rate and higher $\mathrm{HCl}$ in the flue gas for the November test.

- Addition of activated carbon at a rate of $1.5 \mathrm{lb} /$ million acf resulted in an average of $63 \%$ mercury removal in the August tests without any TDF cofiring. A small TDF cofiring rate of about 23 tons per day resulted in an increase in mercury collection to $68 \%$. At the highest TDF rate seen in the August tests of 150-177 tons per day, mercury removal up to $88 \%$ was achieved. This compares with $91 \%$ removal seen during the November tests when the TDF feed rate was in the range from 90 to 250 tons per day. These results indicate that TDF cofiring has the effect of increasing the level of mercury control that can be achieved with a low carbon addition rate.

- Possible approaches to improve mercury capture include batch injection of the carbon or reducing the AHPC current density. At $25 \mathrm{~mA}$ current, mercury emissions were from 0.5 to $0.9 \mu \mathrm{g} / \mathrm{m}^{3}$ lower than at the standard current setting of $55 \mathrm{~mA}$. The short-term power-off tests also showed improved mercury capture. These results suggest that modifying the pulsing sequence or interval could change the flow distribution to enhance the gas-solid contact and improve mercury removal.

- One of the main objectives of these tests was to assess the effect of carbon injection on longer-term AHPC performance. When the carbon was started on August 7, there was no perceptible change in pressure drop or bag-cleaning interval. Similarly, there was no change in the $\mathrm{K}_{2} \mathrm{C}_{\mathrm{i}}$ value that relates to how well the ESP portion of the AHPC is working. These results indicate that low addition rates of carbon will have no perceptible effect on the operational performance of the AHPC.

\subsection{REFERENCES}

1. Zhuang, Y.; Miller, S.J.; Dunham, G.E.; Olderbak, M.R. Mercury Control with the Advanced Hybrid Particulate Collector; January through March Quarterly Technical Progress Report, for U.S. Department of Energy Contract No. DE-FC26-01NT41184; Energy \& Environmental Research Center: Grand Forks, ND, May 2002. 
2. Regulations Impacts on Scrap Tire Combustion: Part II, February 2000 - Section 1. http://www.malcolmpirnie.com/resources_pubs_air_feb00_3.html (Accessed November 8, 2002.)

3. Reisman, J.; E.H. Pechan \& Associates, Inc.; Lemieux, P. Environmental Protection Agency. Air Emissions from Scrap Tire Combustion; EPA-600/R-97-115, Oct 1997.

4. Zhuang, Y.; Miller, S.J.; Olderbak, M.R. Mercury Control with the Advanced Hybrid Particulate Collector; April through June Quarterly Technical Progress Report, for U.S. Department of Energy Contract No. DE-FC26-01NT41184; Energy \& Environmental Research Center: Grand Forks, ND, Aug 2002. 